\title{
Assessing single photon LiDAR for operational implementation of an enhanced forest inventory in diverse mixedwood forests
}

\author{
by Joanne C. White ${ }^{1 *}$, Margaret Penner² and Murray Woods ${ }^{3}$
}

\begin{abstract}
Airborne laser scanning (ALS; LiDAR) data are an increasingly common data source for forest inventories, and approaches integrating ALS data with field plot measurements have become operational in several jurisdictions. As technology continues to evolve, different LiDAR sensors can provide new opportunities to incorporate LiDAR data into forest inventory workflows. Single photon LiDAR (SPL) enables efficient, large area data acquisition and merits further investigation for forest inventory applications. Herein, we investigated the capacity of leaf-on SPL data, combined with 269 field plots, for estimating forest inventory attributes in the Great Lakes-St. Lawrence mixedwood forests of southern Ontario, Canada. Inventory attribute estimates were validated at the stand level using independent reference data acquired for 27 intensively sampled stands. Top height, Lorey's height, gross total volume for merchantable stems, merchantable stem volume, basal area, quadratic mean diameter, and total aboveground biomass were estimated with a relative RMSE of $13.52 \%, 7.24 \%, 14.61 \%, 16.27 \%, 14.42 \%, 12.25 \%$, and $11.72 \%$, respectively. Relative bias was $<1 \%$ for all attributes except top height (10.34\%), merchantable volume (3.37\%), and basal area (1.68\%). Accuracy and bias varied by forest type and stand-level validation was important for assessing model performance in different stand conditions. SPL data can be used to generate accurate, area-based forest inventories in mixedwood forests that have a multitude of tree species and complex forest management histories.
\end{abstract}

Keywords: enhanced forest inventory, LiDAR, temperate forest, ALS, SPL, EFI, PRF

\section{RÉSUMÉ}

Les données de levés laser aéroportés (ALS; LiDAR) deviennent une source de données forestières de plus en plus commune et certaines juridictions intègrent déjà de façon opérationnelle les données ALS aux mesures obtenues sur le terrain. À mesure que la technologie se développe, divers capteurs LiDAR pourraient amener de nouvelles avenues pour l'intégration des données LiDAR aux protocoles d'inventaire forestier. Le LiDAR simple photon (SPL) permet d'acquérir des données efficacement sur de vastes étendues et mérite qu'on s'y intéresse davantage comme outil d'inventaire forestier. Dans cet article, nous avons vérifié s'il était possible d'estimer les paramètres d'inventaire forestier dans des forêts mélangées de la zone des Grands Lacs et du St-Laurent du Sud de l'Ontario (Canada) à partir de données SPL prises sur des arbres en feuilles, combinées à 269 placettes de terrain. Les estimations des paramètres d'inventaire à l'échelle du peuplement ont été validées à partir de données de référence indépendantes, acquises dans 27 peuplements échantillonnées intensivement. Nous avons ainsi estimé la hauteur totale, la hauteur de Lorey, le volume brut et des tiges marchandes, le volume marchand des tiges, la surface terrière, le diamètre moyen quadratique ainsi que la biomasse épigée totale avec une erreur quadratique moyenne de $13,52 \%, 7,24 \%, 14,61 \%, 16,27 \%, 14,42 \%, 12,25 \%$, et $11,72 \%$, respectivement. L'erreur relative a été $<1 \%$ pour tous les paramètres à l'exception de la hauteur totale $(10,34 \%)$, du volume marchand $(3,37 \%)$ et de la surface terrière $(1,68 \%)$. La précision et le biais variaient selon le type de forêt et des validations à l'échelle du peuplement ont été nécessaires pour évaluer la performance du modèle dans différentes conditions de peuplements. Il en ressort que les données SPL peuvent être utilisées pour obtenir des résultats précis d'inventaire forestier par surface dans les forêts mélangées comportant plusieurs essences et un historique d'aménagement complexe.

Mots-clés: Inventaire forestier amélioré, LiDAR, forêt tempérée, ALS, LSP, IFA, FRP

\footnotetext{
${ }^{1}$ Canadian Forest Service (Pacific Forestry Centre), Natural Resources Canada, 506 West Burnside Road, Victoria, British Columbia, V8Z 1M5, Canada; ${ }^{*}$ correspondence: joanne.white@canada.ca

${ }^{2}$ Forest Analysis Ltd., 1188 Walker Lake Dr., RR4, Huntsville, ON P1H 2J6, Canada

${ }^{3}$ Retired - Natural Resources Information Section, Science and Research Branch, Ontario Ministry of Natural Resources and Forestry. 3301 Trout Lake Road, North Bay, Ontario, P1A 4L7, Canada
} 


\section{Introduction}

Airborne LiDAR (Light Detection and Ranging) has been a transformative technology, providing detailed characterizations of the earth's surface and three-dimensional measures of forest structure. The increase in spatial detail and precision afforded by LiDAR is critical for a broad range of natural resource management applications (Eitel et al. 2016), including forest inventory (Wulder et al. 2008; Hyyppä et al. 2012). In the last decade, the use of LiDAR for forest inventory has moved from the realm of research to operational implementation (Næsset 2015), particularly for area-based modelling (Næsset 2002; White et al. 2013, 2017). The efficacy of LiDAR for forest inventory has been comprehensively demonstrated in many different forest types, including in Canada's boreal forest (Thomas et al. 2006; Woods et al. 2008, 2011; Treitz et al. 2012; Penner et al. 2013, 2015). The LiDAR data used in these aforementioned studies were acquired from discrete return or full waveform airborne LiDAR sensors, which are hereafter referred to collectively as "linear-mode LiDAR" (hereafter LML; Stoker et al. 2016). Single photon LiDAR (SPL), which has only been commercialized within the past five years, represents a potential significant technological advance in the capacity to efficiently characterize forest structure and terrain over very large areas, with a single sensor and consistent acquisition parameters.

In a forestry context, discrete-return small footprint $\mathrm{LiDAR}$ is the most common form of LiDAR technology currently in use (White et al. 2016). These systems operate by emitting a laser pulse and measuring the time it takes for that pulse to return to the sensor. As a porous target, forest canopies allow laser pulses to penetrate through small canopy openings, with some of the laser pulse's energy returning to the sensor each time a laser pulse is intercepted by an object (e.g., a leaf, branch, or ground). Advances in the development of discrete return LiDAR sensors have been rapid over the past two decades (Nelson 2013). A particular focus has been on increasing the pulse repetition frequency of sensors, which enable aircraft to fly higher and faster, allowing data to be acquired over a larger area in a fixed amount of flying time, while still maintaining or increasing the pulse density. Although there are speed-of-light limitations to increasing the pulse repetition frequency (i.e., the energy from the emitted pulse must return to the instrument before another pulse can be emitted in order to prevent range ambiguities), software solutions enabling a multiple-pulses-in-the-air configuration have largely addressed this challenge (Nelson 2013). However, increasing the pulse repetition frequency can also result in less energy for each laser pulse, reducing the likelihood of the pulse penetrating the canopy and likewise decreasing the probability of multiple returns being recorded for each emitted pulse. Discrete return systems are able to record multiple returns (commonly five returns per pulse) of energy for each laser pulse; however the amount of energy (i.e., the number of photons) required to trigger a return at the sensor is proprietary to each instrument, and is in the order of hundreds or thousands of photons (Brown et al. 2020). In contrast, in an SPL system, a single photon can trigger a return at the sensor, allowing for lower energy laser pulses to be emitted at higher densities from higher acquisition altitudes. Currently the only commercial SPL system, the SPL100, splits each emitted laser pulse into a $10 \times 10$ array of
100 beamlets and the returned energy from each beamlet is recorded onto an array of highly sensitive detectors. These detectors have a very short recovery time, which allows them to record multiple returns from each emitted laser pulse. These sensitive detectors, combined with the high repetition rate of the transmitter, represent the operational advantage of SPL technology. However, while many conventional LML instruments operate at near-infrared wavelengths $(1064 \mathrm{~nm})$, current SPL instruments (i.e., SPL100) operate at green wavelengths $(532 \mathrm{~nm})$ and are thus sensitive to solar noise, highlighting a need for efficient noise filtering algorithms for SPL data (Li et al. 2016; Stoker et al. 2016; Brown et al. 2020).

As a result of the aforementioned limitations, LML data has typically been acquired at lower altitudes (e.g., $750 \mathrm{~m}$ agl versus $3800 \mathrm{~m}$ for the SPL) and slower flying speeds $(<100$ knots compared to 180 knots for the SPL), both of which increase flying time and data acquisition costs (White et al. 2013). The advantages of SPL for large area data collection and potential cost savings are compelling reasons to investigate the capabilities of the SPL technology for forest inventory. For example, Wästlund et al. (2018) quantified the potential efficiencies of the SPL100 for data acquisition, estimating that in their study area in the boreal forests of southern Sweden, the SPL100 covered $590 \mathrm{~km}^{2} /$ hour compared to $50 \mathrm{~km}^{2} /$ hour for the Optech Titan system. Likewise, Mandlburger et al. (2019) quantified some of the economies afforded by the SPL100 instrument, using a target last return pulse density of 20 pulses $/ \mathrm{m}^{2}$ for a $160 \mathrm{~km}^{2}$ area. To meet the target, the SPL (acquired from $4000 \mathrm{~m}$ agl) required five flight lines with $20 \%$ overlap. By comparison, the LML required 18 flight lines with $50 \%$ overlap flown at an altitude of $750 \mathrm{~m}$ agl to meet the target pulse density. Thus, the SPL swath width was more than twice that of the LML ( $2400 \mathrm{~m}$ vs. $840 \mathrm{~m}$ ) and the SPL data were acquired at an altitude that was five times greater than the LML. Yu et al. (2020) likewise documented that the SPL100 required one-fifth the number of flight lines acquired by an Optech Titan instrument to cover their study area in southern Finland.

Beyond the plot-level analyses reported in Wästlund et al. (2018) and Yu et al. (2020) in boreal forests, a full implementation and validation of an enhanced forest inventory (EFI) using SPL data across a range of forest types has been limited in the scientific literature. Previous research has focused on characterizing the accuracy of vegetation heights and terrain elevations, with several studies using SPL data from the HRQLS instrument (Li et al. 2016; Stoker et al. 2016; Swatantran et al. 2016), the precursor to the Leica SPL100. Performance results from the HRQLS instrument were mixed, with noise filtering highlighted as a key issue with these data. For example, using 176 National Geodetic Benchmarks, Swatantran et al. (2016), reported an RMSE of $3.78 \mathrm{~m}$ and a bias of $-2.12 \mathrm{~m}$ for terrain elevations derived from the HRQLS data. Subsequent studies have assessed data from the SPL100 instrument (Mandlburger et al. 2019; Brown et al. 2020) with more promising performance results in terms of accurate aboveground and terrain height capture. Using 33 survey-grade GNSS checkpoints in a relatively flat area; Brown et al. (2020) reported an average vertical bias of 11.67 $\mathrm{cm}(\mathrm{sd}=7.63 \mathrm{~cm})$ for the SPL100 data.

Wästlund et al. (2018) provided the first assessment of the use of SPL100 data in an area-based approach for estimating 
forest inventory attributes. The authors compared the results from the SPL100 data to those obtained using Optech Titan data (using only the $1064 \mathrm{~nm}$ wavelength data from the Titan). Their study area was hemi-boreal and the SPL data were acquired in leaf-off conditions, whereas the Titan data were leaf-on. Using 184 sample plots dominated by evergreen coniferous trees (i.e., $>50 \%$ by volume), the authors modelled Lorey's mean height, stem volume, aboveground biomass, basal area, and basal area weighted diameter. Using leaveone-out cross-validation on the plot data, the authors found that-with the exception of basal area-the SPL data gave marginally better estimates than the Titan data; however differences in estimation error were $<1 \%$ on average. Estimation differences were greatest for stem volume (3\% difference in RMSE\%) and lowest for Lorey's mean height $(0.13 \%$ difference in RMSE\%). In a similar study, Yu et al. (2020) also compared the SPL100 and Optech Titan leaf-on data for an ABA using 87 sample plots to model Lorey's mean height, quadratic mean diameter, volume, and aboveground biomass in pine, spruce, and birch-dominated stands. Yu et al. (2020) reported that the out-of-bag error from their random forests model (RMSE\%) for the four attributes predicted from the two datasets differed by $<1 \%$.

Previous studies that have explored the capability of SPL for forest inventory were conducted in boreal forests with few tree species and relatively simple forest structures. Our objective in this work was to comprehensively assess the application of SPL data in an operational area-based approach to forest inventory in a temperate forest environment with a multitude of tree species and complex forest management histories. To achieve this, we predicted a broad suite of forest inventory attributes and quantified how model performance varied by attribute and by forest type. We assessed model predictions at both the plot level (as done in past studies) and, unique to this study, at the forest stand level using independent and intensively sampled stand-level validation data. These validation data enabled our comprehensive evaluation of SPL's performance at a spatial unit that is relevant for forest management and planning.

\section{Materials and methods Study area}

Located approximately $200 \mathrm{~km}$ northwest of Ottawa, Canada, the study area encompassed 10000 ha of forest land located in the Petawawa Research Forest (PRF) and an adjacent 5000 ha of forest land managed by the Canadian Nuclear Laboratory (CNL; Fig. 1). The PRF was established in 1918 and is the oldest, continuously operated research forest in Canada (Place 2002), and the site of a multitude of remotely sensed and reference data acquisitions (White et al. 2019). Located in the Great Lakes-St. Lawrence forest region (Rowe 1972), the forests of both the PRF and CNL sites are dominated by mature mixedwood stands ( $70 \%$ by area) with remaining stands being primarily hardwood $(22 \%)$ or conifer (8\%) dominated. Common tree species include eastern white pine (Pinus strobus L.), trembling aspen (Populus tremuloides Michx.), red oak (Quercus rubra L.), red pine (Pinus resinosa Ait.), white birch (Betula papyrifera Marsh.), white spruce (Picea glauca (Moench) Voss), and several species of maple (Acer spp.), among others (Wetzel et al. 2011). This forest region is considered a transition between the boreal forests to the north, which are dominated by coniferous species, and the deciduous-dominated forests to the south. Tree species that are more common in boreal forests, such as jack pine (Pinus banksiana Lamb.) and black spruce (Picea mariana (Mill.) B.S.P.) are also found on suitable sites within the study area. As a research forest, the study area is characterized by complex management histories, with several long-term conifer plantation studies and management trials (D'Eon et al. 2006).

\section{Data}

\section{Ground plot calibration data}

A total of 269 circular fixed-area plots (14.1 m radius, $625 \mathrm{~m}^{2}$ ) were used as calibration data for this project. In addition, small tree plots with a radius of $3.99 \mathrm{~m}\left(50 \mathrm{~m}^{2}\right)$ were nested within the larger plots and located at the plot centroid. Ground plots were located to cover the full range of species and stand development in 12 different forest types (Table 1), following a structurally-guided sampling approach (White et al. 2013). The position of the plot centroid was recorded using a TopCon ${ }^{\text {Tw }}$ GPS unit with a minimum 60 minute static collection for each plot centre. Plot positions were later postprocessed using the Canadian Spatial Reference System Precise Point Positioning Tool (Natural Resources Canada 2020). Live and dead trees with a diameter at breast height $(\mathrm{DBH}) \geq 9.1 \mathrm{~cm}$ were measured for each plot. While DBH was measured on all trees, only a subsample was measured for height. A height sample was measured at each plot throughout the range of diameters and species, with the four largest trees of the dominant plot species measured at each plot. In addition, all trees with $2.5<\mathrm{DBH}<9.1 \mathrm{~cm}$ were measured within the small tree plot. Height measurements were made using a Vertex hypsometer. Other recorded attributes include tree status (live, dead, fallen down, harvested), species, origin (natural, planted, coppice, layering), crown class (codominant, dominant, emergent, intermediate, overtopped/suppressed, anomaly) and for dead trees, the decay class.

Plot measurements were then compiled to provide a suite of plot-level attributes. Height-DBH curves were fit at the plot level (Eq. 1), with all species combined, and used to estimate heights for those trees without measured heights. The average dominant/codominant height was calculated as the average height of the live dominant/codominant/emergent trees with measured heights. Only the trees with $\mathrm{DBH} \geq 9.1$ $\mathrm{cm}$ on the large tree plot had crown status recorded. The Sharma (2016) equation was used for height:

$$
\left.H t=1.3+\alpha \cdot S H t^{\delta} \cdot\left(1-e^{-\beta \cdot(T P H / B A}\right)^{\cdot \varphi_{D B H}}\right)^{\gamma}
$$

Where:

Ht is total tree height (m)

$\mathrm{DBH}$ is diameter at breast height $(\mathrm{cm})$

BA is stand basal area $\left(\mathrm{m}^{2} / \mathrm{ha}\right)$

$\mathrm{TPH}$ is stand density (trees/ha)

SHt is stand height (dominant/codominant height of the plot)

$\alpha, \beta, \gamma, \delta$, and $\phi$ are parameters to be estimated

Stem volumes were estimated using the Zakrzewski and Penner (2013) and Sharma and Parton (2009) models. 


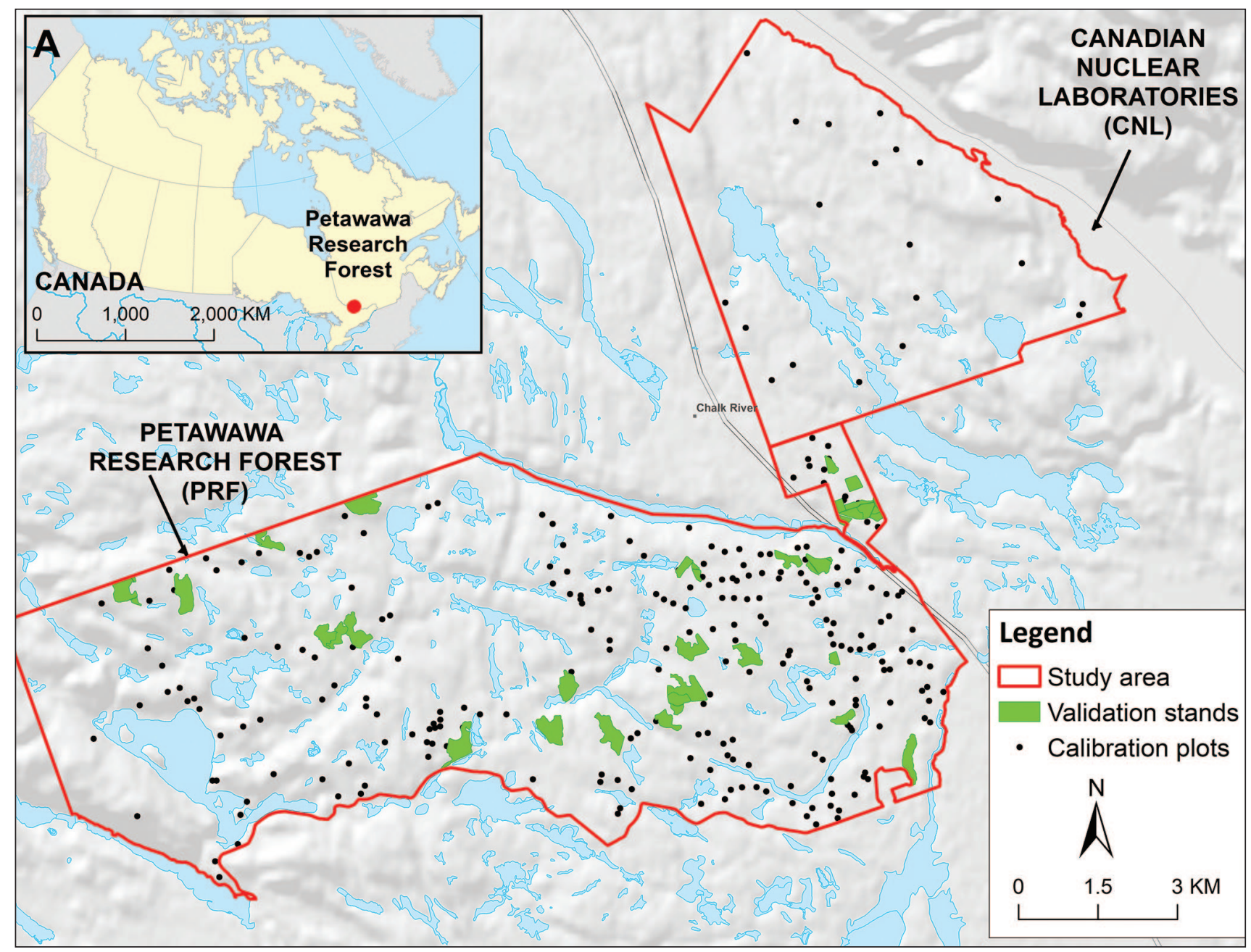

Fig. 1 Study area comprised of the Petawawa Research Forest (PRF) and adjacent Canadian Nuclear Laboratories (CNL) lands. Shown are the locations of calibration plots used for model development and out-of-bag (OOB) error assessment as well as the independent, intensively sampled validation stands

Biomass was estimated using the equations of Lambert et al. (2005) using height and DBH. A summary of the calibration data, by forest type, is provided in Table 2 and variability in forest conditions in the ground plots is exemplified in Fig. 2.

\section{Stand-level validation data}

Based on forest type information in the existing PRF operational forest inventory representing circa 2000 conditions, a total of 27 mature forest stands representing 10 of the 12 different forest types were intensively sampled to provide standlevel reference data for validating model outcomes (Table 3). A $50 \mathrm{~m}$ x $50 \mathrm{~m}$ sampling grid was superimposed on each validation stand and sampling station locations were identified (Fig. 3). A maximum stand size of 15 ha was selected to maintain approximately 50 stations per stand; however in many cases, fewer stations were identified within the selected stands as a function of stand size and shape. Stations located along the $50 \mathrm{~m} \times 50 \mathrm{~m}$ grid were adjusted as necessary to maintain a minimum distance of $20 \mathrm{~m}$ from clearly marked trails and roads. Each sampled stand was also buffered internally by
$12.5 \mathrm{~m}$ to ensure that sampling would be contained to the target stand condition. A GPS was used to navigate to the identified stand-station waypoint, with a target accuracy of within $5 \mathrm{~m}$ of the target station location. At each station, a BAF-2 prism was used to identify each tree determined to be in (i.e., $\mathrm{DBH} \geq 9.1 \mathrm{~cm}$ ). Each live in tree was recorded for species, $\mathrm{DBH}$, and quality. In addition, the tree with the largest $\mathrm{DBH}$ for each prism sweep was measured for height (or the next largest tree if form of the largest had been previously seriously impacted). Borderline trees were checked with a limiting distance table. A total of 1001 BAF-2 prism plots were used to derive validation summary information on 27 stands (Table 3). These validation data are completely independent and were not used for model development or calibration. In the comparison between observed and predicted stand-level attributes, the observed attribute for each stand is the arithmetic average of the field samples (i.e., cruise stations) found within that stand. The predicted attribute is the arithmetic average of the SPL-derived grid cell area-based estimates within the stand. 
Table 1. Description of forest types associated with calibration and validation data. CP = calibration plots; VS = validation stands. Note that calibration plots in spruce and white pine plantations sampled a range of forest structures associated with various initial planting densities and subsequent management activities and that no validation data were acquired for these forest types.

\begin{tabular}{ll}
\hline Forest type & Description \\
\hline Black Spruce & $\begin{array}{l}\text { CP sampled a range of structures found within natural lowland dominated stands and some upland unmanaged } \\
\text { plantations. VS sampled natural stand conditions. }\end{array}$
\end{tabular}

Jack Pine

Lowland Conifer

Mixedwood

Oak

Poplar

Red Pine Plantation

Spruce Plantation

Tolerant Hardwood

Pine Managed

Pine Natural

White Pine Plantation CP sampled a range of various initial planting densities and subsequent management activiites. No validation data were acquired for this forest type.

\section{Single-photon LiDAR (SPL) data}

Leaf-on single photon LiDAR data were acquired for the Petawawa Research Forest and the adjoining Canadian Nuclear Laboratory property on July 2, 2018. The Leica SPL100 sensor was flown aboard a Piper-PA-31-350 at an average altitude of $3800 \mathrm{~m}$ and an average flying speed of 180 knots. The SPL swath width was $2000 \mathrm{~m}$, with an aggregate nominal pulse density of 32.4 pulses $/ \mathrm{m}^{2}$. Noise filtering of the SPL data was performed by the data provider using the approach detailed in Gluckman (2016). To support areabased modelling, LiDAR metrics were calculated from the SPL point clouds (Table S1). These LiDAR metrics are statistical summaries of the LiDAR 3D point cloud representing the height and distribution of vegetation through the vertical profile of the canopy and are used as predictors to develop models for forest inventory attributes of interest following the approach outlined in White et al. (2013, 2017). SPL LiDAR metrics were generated with LAStools (version 190812; Isenburg 2020) using the full SPL point cloud (all returns), without the application of a height threshold. Example SPL point clouds for some of forest types in the study area are shown in Fig. 4.

\section{Area-based modeling approach}

Attributes were modelled using random forests (Breiman 2001 ), as implemented in the $R$ package randomForest (Liaw and Weiner 2002). No stratification was used for model development. Forest inventory attributes that were predicted directly are defined in Table 4. Merchantable attributes were only predicted when the $99^{\text {th }}$ percentile of point cloud height (P99) was $>5 \mathrm{~m}$. Attributes that were not predicted directly, but rather derived from other predicted attributes, are 
Table 2. Summary of calibration plot data, which cover a range of forest conditions within the study area. Attributes are for all stems. $\mathbf{N}$ is the number of plots for each forest type. The mean value is followed by the standard deviation and the range of values is provided in parentheses.

\begin{tabular}{|c|c|c|c|c|c|c|}
\hline Forest Type & $\mathbf{N}$ & Top height (m) & $\begin{array}{c}\text { Gross total } \\
\text { volume, } \\
\text { merchantable } \\
\text { stems }\left(\mathbf{m}^{3} / \mathrm{ha}\right) \\
\text { TVOL_merch }\end{array}$ & $\begin{array}{c}\text { Merchantable } \\
\text { stem volume } \\
\left(\mathrm{m}^{3} / \mathrm{ha}\right) \\
\text { MVOL }\end{array}$ & $\begin{array}{c}\text { Basal area, } \\
\text { merchantable } \\
\text { stems }\left(\mathbf{m}^{2} / \mathbf{h a}\right) \\
\text { BA_merch }\end{array}$ & $\begin{array}{c}\text { Quadratic } \\
\text { mean diameter } \\
\text { (cm)DQ_merch }\end{array}$ \\
\hline Black Spruce & 14 & $\begin{array}{c}18.47 \\
3.56 \\
(10.65-22.20)\end{array}$ & $\begin{array}{c}145.15 \\
65.82 \\
(19.02-244.29)\end{array}$ & $\begin{array}{c}122.55 \\
58.36 \\
(9.60-197.28)\end{array}$ & $\begin{array}{c}18.88 \\
7.55 \\
(4.00-32.89)\end{array}$ & $\begin{array}{c}16.24 \\
2.74 \\
(10.66-20.48)\end{array}$ \\
\hline Jack Pine & 10 & $\begin{array}{c}21.44 \\
2.41 \\
(16.86-24.71)\end{array}$ & $\begin{array}{c}175.36 \\
43.46 \\
(106.74-260.83)\end{array}$ & $\begin{array}{c}150.97 \\
35.93 \\
(77.08-197.83)\end{array}$ & $\begin{array}{c}19.34 \\
3.26 \\
(14.67-26.21)\end{array}$ & $\begin{array}{c}18.57 \\
2.78 \\
(14.06-23.28)\end{array}$ \\
\hline Lowland Conifer & 4 & $\begin{array}{c}19.3 \\
3.46( \\
15.63-22.64)\end{array}$ & $\begin{array}{c}218.05 \\
120.98 \\
(73.82-360.48)\end{array}$ & $\begin{array}{c}179.99 \\
106.33 \\
(55.51-298.57)\end{array}$ & $\begin{array}{c}28.95 \\
13.32 \\
(11.56-43.90)\end{array}$ & $\begin{array}{c}20.33 \\
5.13 \\
(14.46-26.98)\end{array}$ \\
\hline Mixedwood & 41 & $\begin{array}{c}21.57 \\
4.56 \\
(11.98-29.15)\end{array}$ & $\begin{array}{c}180.38 \\
87.94 \\
(19.90-342.40)\end{array}$ & $\begin{array}{c}139.86 \\
76.17 \\
(2.12-313.01)\end{array}$ & $\begin{array}{c}21.47 \\
8.51 \\
(3.85-36.36)\end{array}$ & $\begin{array}{c}18.99 \\
3.35 \\
(11.56-26.34)\end{array}$ \\
\hline Oak & 13 & $\begin{array}{c}21.26 \\
4.60 \\
(13.80-27.47)\end{array}$ & $\begin{array}{c}165.77 \\
88.01 \\
(2.83-297.89\end{array}$ & $\begin{array}{c}117.32 \\
84.91 \\
(0.69-247.38)\end{array}$ & $\begin{array}{c}18.58 \\
8.98 \\
(0.45-28.96)\end{array}$ & $\begin{array}{c}21.59 \\
5.73 \\
(13.82-34.30)\end{array}$ \\
\hline Poplar & 15 & $\begin{array}{c}27.62 \\
5.48 \\
(16.57-35.08)\end{array}$ & $\begin{array}{c}389.75 \\
204.68 \\
(108.86-796.53)\end{array}$ & $\begin{array}{c}324.88 \\
204.48 \\
(20.22-739.74)\end{array}$ & $\begin{array}{c}33.81 \\
13.43 \\
(11.21-55.74)\end{array}$ & $\begin{array}{c}23.52 \\
5.84 \\
(12.78-32.12)\end{array}$ \\
\hline Red Pine Plantation & 23 & $\begin{array}{c}23.63 \\
7.92 \\
(9.82-34.55)\end{array}$ & $\begin{array}{c}425.74 \\
242.72 \\
(110.91-999.55)\end{array}$ & $\begin{array}{c}371.50 \\
248.96 \\
(21.80-935.16)\end{array}$ & $\begin{array}{c}39.11 \\
12.98 \\
(22.66-70.70)\end{array}$ & $\begin{array}{c}24.87 \\
7.32 \\
(12.36-38.23)\end{array}$ \\
\hline Spruce Plantation & 12 & $\begin{array}{c}21.36 \\
5.23 \\
(15.27-31.38)\end{array}$ & $\begin{array}{c}229.36 \\
118.70 \\
(100.33-457.76)\end{array}$ & $\begin{array}{c}201.02 \\
110.12 \\
(86.91-401.81)\end{array}$ & $\begin{array}{c}28.21 \\
10.39 \\
(12.19-52.46)\end{array}$ & $\begin{array}{c}21.55 \\
3.88 \\
(16.71-28.33)\end{array}$ \\
\hline Tolerant Hardwood & 23 & $\begin{array}{c}25.95 \\
4.74 \\
(15.57-34.41)\end{array}$ & $\begin{array}{c}265.52 \\
115.96 \\
(41.98-483.32)\end{array}$ & $\begin{array}{c}210.01 \\
114.10 \\
(23.09-441.77)\end{array}$ & $\begin{array}{c}27.17 \\
9.40 \\
(6.50-43.90)\end{array}$ & $\begin{array}{c}26.95 \\
6.05 \\
(15.54-36.42)\end{array}$ \\
\hline Pine Managed & 14 & $\begin{array}{c}20.29 \\
4.24 \\
(11.75-25.27)\end{array}$ & $\begin{array}{c}202.62 \\
97.51 \\
(25.35-336.34)\end{array}$ & $\begin{array}{c}161.73 \\
80.08 \\
(18.06-271.40)\end{array}$ & $\begin{array}{c}24.91 \\
11.19 \\
(3.48-37.21)\end{array}$ & $\begin{array}{c}24.03 \\
5.09 \\
(17.55-38.79)\end{array}$ \\
\hline Pine Natural & 93 & $\begin{array}{c}28.33 \\
7.01 \\
(8.28-45.66)\end{array}$ & $\begin{array}{c}357.73 \\
220.80 \\
(18.98-947.89)\end{array}$ & $\begin{array}{c}323.13 \\
214.25 \\
(8.48-911.34)\end{array}$ & $\begin{array}{c}30.78 \\
15.27 \\
(2.26-63.80)\end{array}$ & $\begin{array}{c}30.06 \\
10.59 \\
(11.55-71.22)\end{array}$ \\
\hline White Pine Plantation & 7 & $\begin{array}{c}19.84 \\
11.54 \\
(5.95-37.90)\end{array}$ & $\begin{array}{c}221.61 \\
123.95 \\
(84.93-433.35)\end{array}$ & $\begin{array}{c}166.33 \\
137.15 \\
(0.00-416.94)\end{array}$ & $\begin{array}{c}25.16 \\
10.65 \\
(16.23-44.44)\end{array}$ & $\begin{array}{c}29.98 \\
12.97 \\
(18.38-51.26)\end{array}$ \\
\hline Overall & 269 & $\begin{array}{c}24.46 \\
6.91 \\
(5.95-45.66)\end{array}$ & $\begin{array}{c}284.11 \\
192.18 \\
(2.83-999.55)\end{array}$ & $\begin{array}{c}242.92 \\
187.27 \\
(0.00-935.16)\end{array}$ & $\begin{array}{c}27.72 \\
13.31 \\
(0.45-70.70)\end{array}$ & $\begin{array}{c}24.88 \\
8.91 \\
(10.66-71.21)\end{array}$ \\
\hline
\end{tabular}




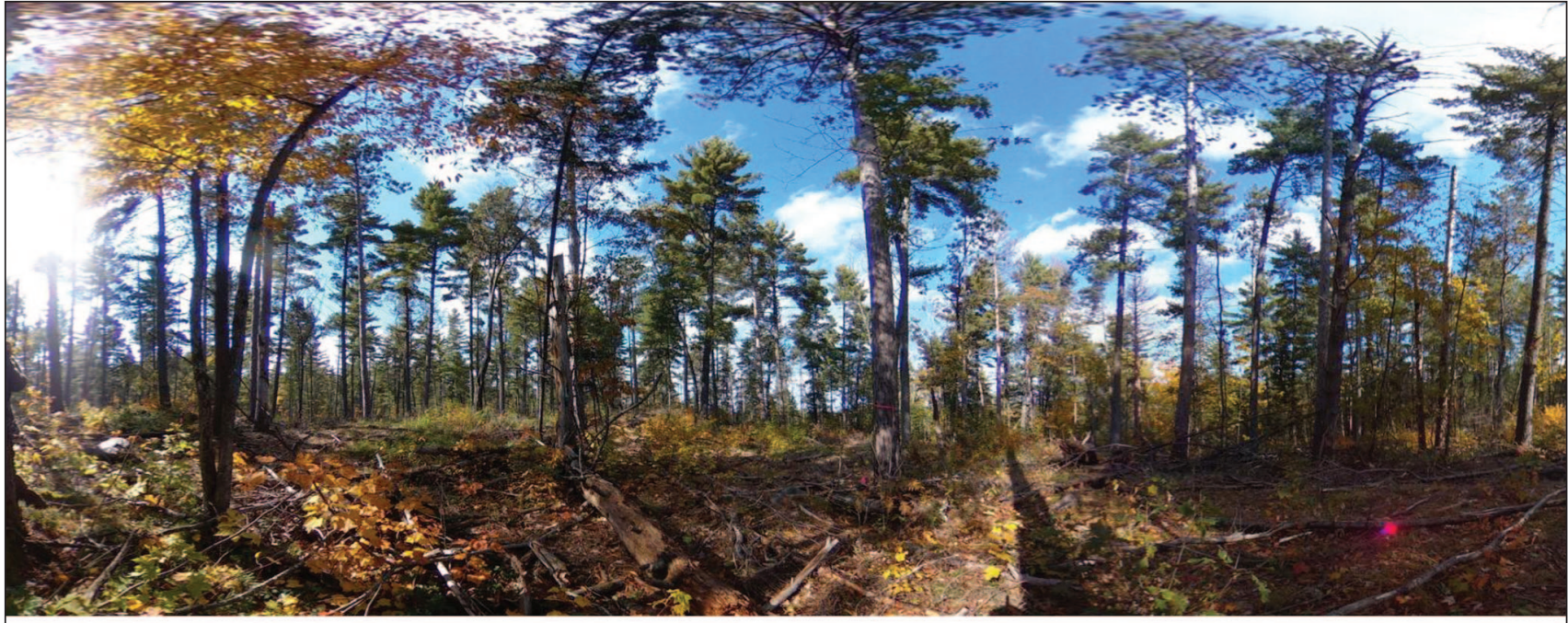

\section{Pine managed (PRF199)}

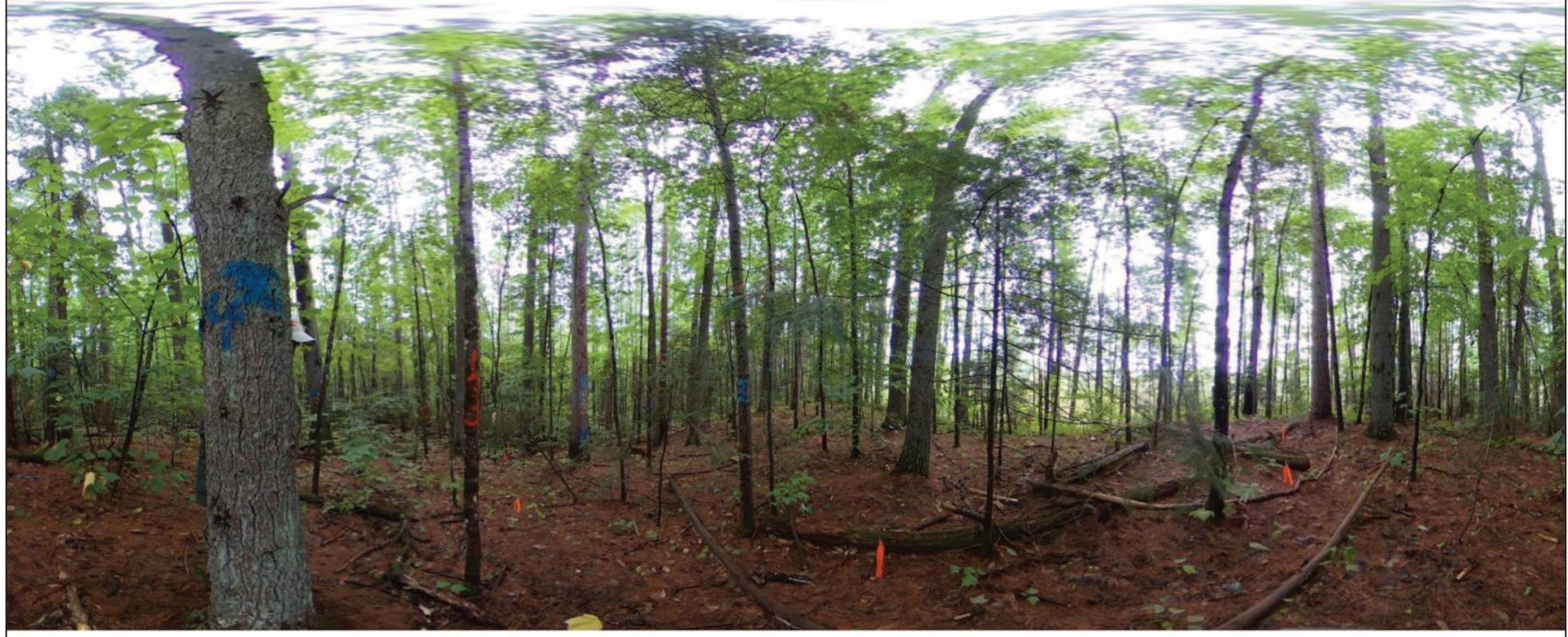

\section{Pine natural (PRF185)}

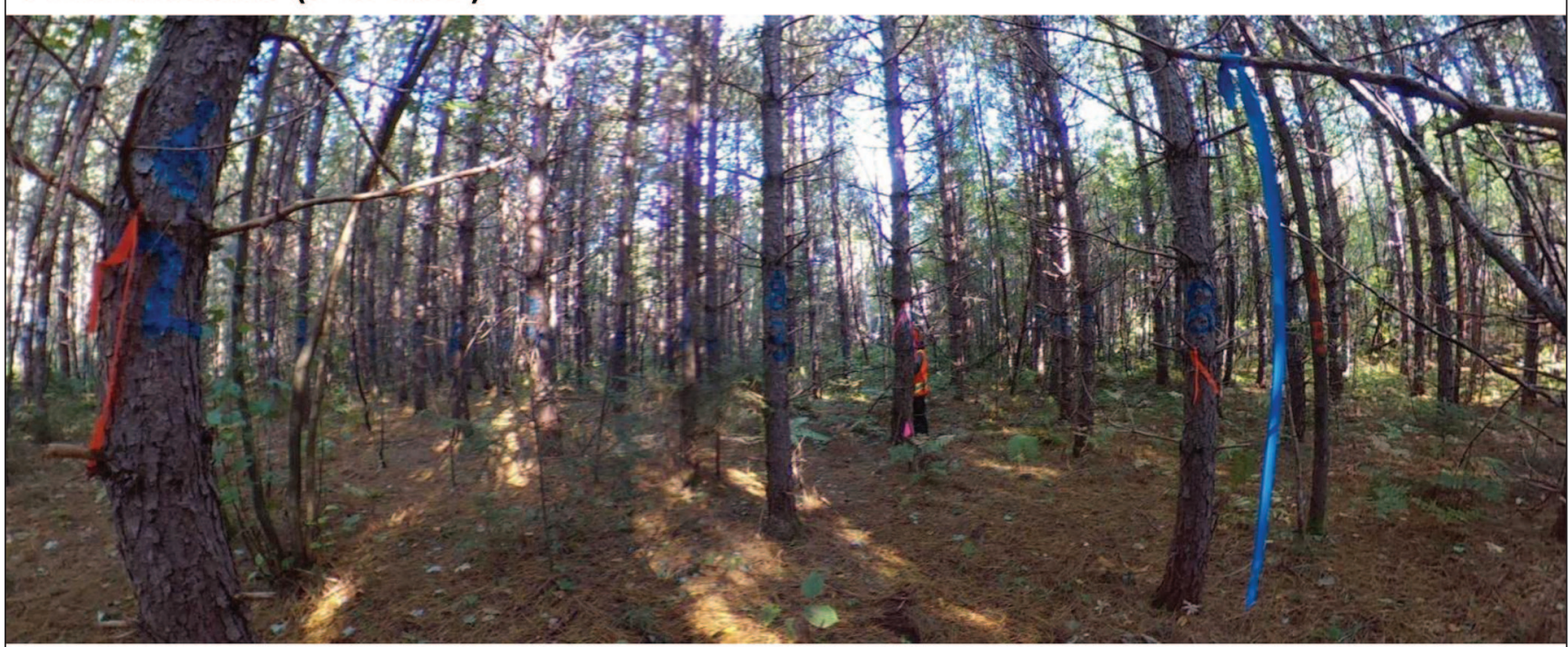

\section{Red pine plantation (PRF010)}

Fig. 2 Photos taken from the plot centroid for three calibration plots in a pine managed stand, a natural pine stand, and a red pine plantation 
Table 3. Summary of stand-level validation data for the PRF; mean value is followed by the range of values in parentheses

\begin{tabular}{|c|c|c|c|c|c|c|c|c|}
\hline Forest Type & $\begin{array}{l}\text { Number } \\
\text { of stands }\end{array}$ & $\begin{array}{c}\text { Area } \\
\text { (ha) }\end{array}$ & $\begin{array}{c}\begin{array}{c}\text { Number } \\
\text { of BAF-2 }\end{array} \\
\text { prism plots } \\
\text { Total } \\
\text { (average) }\end{array}$ & $\begin{array}{c}\text { Top height } \\
\text { (m) }\end{array}$ & $\begin{array}{c}\text { Gross total } \\
\text { volume } \\
\text { merchantable } \\
\text { stems (m³/ha) } \\
\text { TVOL_merch }\end{array}$ & $\begin{array}{c}\text { Merchantable } \\
\text { stem volume } \\
\left(\mathrm{m}^{3} / \mathrm{ha}\right) \\
\text { MVOL }\end{array}$ & $\begin{array}{c}\text { Basal area, } \\
\text { merchantable } \\
\text { stems }\left(\mathbf{m}^{2} / \mathrm{ha}\right) \\
\text { BA_merch }\end{array}$ & $\begin{array}{c}\text { Quadratic } \\
\text { mean } \\
\text { diameter } \\
(\mathrm{cm}) \\
\text { DQ_merch }\end{array}$ \\
\hline Black Spruce & 2 & $\begin{array}{c}7 \\
(7-8)\end{array}$ & $\begin{array}{c}43 \\
(22)\end{array}$ & $\begin{array}{c}19.6 \\
(19.0-20.1)\end{array}$ & $\begin{array}{c}185.3 \\
(178.3-192.3)\end{array}$ & $\begin{array}{c}152.0 \\
(145.3-158.8)\end{array}$ & $\begin{array}{c}22.4 \\
(22.3-22.5)\end{array}$ & $\begin{array}{c}19.7 \\
(18.9-20.4)\end{array}$ \\
\hline Jack Pine & 2 & $\begin{array}{c}9 \\
(6-12)\end{array}$ & $\begin{array}{c}56 \\
(28)\end{array}$ & $\begin{array}{c}20.3 \\
(19.6-21.0)\end{array}$ & $\begin{array}{c}206 \\
(197.9-213.6)\end{array}$ & $\begin{array}{c}183.0 \\
(178.0-188.0)\end{array}$ & $\begin{array}{c}22.3 \\
(21.3-23.2)\end{array}$ & $\begin{array}{c}19.4 \\
(18.5-20.2)\end{array}$ \\
\hline Lowland Conifer & 1 & $\begin{array}{c}15 \\
(15-15)\end{array}$ & $\begin{array}{c}47 \\
(47)\end{array}$ & $\begin{array}{c}15.5 \\
(15.5-15.5)\end{array}$ & $\begin{array}{c}150.1 \\
(150.1-150.1)\end{array}$ & $\begin{array}{c}124.6 \\
(124.6-124.6)\end{array}$ & $\begin{array}{c}23.4 \\
(23.4-23.4)\end{array}$ & $\begin{array}{c}19.2 \\
(19.2-19.2)\end{array}$ \\
\hline Mixedwood & 4 & $\begin{array}{c}18 \\
(16-19)\end{array}$ & $\begin{array}{l}210 \\
(53)\end{array}$ & $\begin{array}{c}19.9 \\
(18.8-20.5)\end{array}$ & $\begin{array}{c}220.9 \\
(204.6-229.3)\end{array}$ & $\begin{array}{c}168 . \\
0(151.3-176.3)\end{array}$ & $\begin{array}{c}26.8 \\
(24.0-28.6)\end{array}$ & $\begin{array}{c}20.3 \\
(19.3-21.0)\end{array}$ \\
\hline Oak & 2 & $\begin{array}{c}19 \\
(19-20)\end{array}$ & $\begin{array}{l}110 \\
(55)\end{array}$ & $\begin{array}{c}21.5 \\
(21.2-21.9)\end{array}$ & $\begin{array}{c}278.6 \\
(246.7-310.4)\end{array}$ & $\begin{array}{c}228.6 \\
(201.5-255.7)\end{array}$ & $\begin{array}{c}29.6 \\
(27.4-31.8)\end{array}$ & $\begin{array}{c}24.7 \\
(24.3-25.0)\end{array}$ \\
\hline Poplar & 2 & $\begin{array}{c}7 \\
(4-9)\end{array}$ & $\begin{array}{c}35 \\
(18)\end{array}$ & $\begin{array}{c}23.1 \\
(22.5-23.6)\end{array}$ & $\begin{array}{c}254.5 \\
(222.7-286.4)\end{array}$ & $\begin{array}{c}209.7 \\
(187.5-231.9)\end{array}$ & $\begin{array}{c}24.7 \\
(21.9-27.5)\end{array}$ & $\begin{array}{c}20.5 \\
(19.0-21.9)\end{array}$ \\
\hline Red Pine Plantation & 4 & $\begin{array}{c}5 \\
(4-9)\end{array}$ & $\begin{array}{c}65 \\
(16)\end{array}$ & $\begin{array}{c}22.9 \\
(20.5-25.5)\end{array}$ & $\begin{array}{c}330.1 \\
(230.6-429.3)\end{array}$ & $\begin{array}{c}294.6 \\
(216.4-395.6)\end{array}$ & $\begin{array}{c}31.6 \\
(21.4-38.5)\end{array}$ & $\begin{array}{c}26.3 \\
(21.2-32.6)\end{array}$ \\
\hline Pine Managed & 3 & $\begin{array}{c}12 \\
(9-16)\end{array}$ & $\begin{array}{l}108 \\
(36)\end{array}$ & $\begin{array}{c}29.3 \\
(25.8-33.8)\end{array}$ & $\begin{array}{c}173.5 \\
(102.6-212.5)\end{array}$ & $\begin{array}{c}161.0 \\
(94.6-201.0)\end{array}$ & $\begin{array}{c}15.0 \\
(9.0-19.7)\end{array}$ & $\begin{array}{c}35.7 \\
(31.9-41.4)\end{array}$ \\
\hline Pine Natural & 4 & $\begin{array}{c}13 \\
(10-19)\end{array}$ & $\begin{array}{l}160 \\
(40)\end{array}$ & $\begin{array}{c}23.5 \\
(21.9-25.2)\end{array}$ & $\begin{array}{c}308.2 \\
(292.0-315.6)\end{array}$ & $\begin{array}{c}266.5 \\
(248.8-285.1)\end{array}$ & $\begin{array}{c}31.5 \\
(30.1-32.9)\end{array}$ & $\begin{array}{c}24.2 \\
(23.2-25.5)\end{array}$ \\
\hline Tolerant Hardwood & 3 & $\begin{array}{c}18 \\
(14-21)\end{array}$ & $\begin{array}{l}167 \\
(56)\end{array}$ & $\begin{array}{c}20.7 \\
(20.2-21.7)\end{array}$ & $\begin{array}{c}232.8 \\
(206.3-248.6)\end{array}$ & $\begin{array}{c}177.6 \\
(148.5-195.1)\end{array}$ & $\begin{array}{c}27.5 \\
(25.1-29.7)\end{array}$ & $\begin{array}{c}21.0 \\
(20.4-21.5)\end{array}$ \\
\hline Overall & 27 & $\begin{array}{c}13 \\
(4-21)\end{array}$ & $\begin{array}{l}1001 \\
(37)\end{array}$ & $\begin{array}{c}22.2 \\
(15.5-33.8)\end{array}$ & $\begin{array}{c}246.5 \\
(102.6-429.3)\end{array}$ & $\begin{array}{c}207.5 \\
(94.6-395.9)\end{array}$ & $\begin{array}{c}26.2 \\
(9.0-38.5)\end{array}$ & $\begin{array}{c}23.7 \\
(18.5-41.4)\end{array}$ \\
\hline
\end{tabular}

defined in Table 5. Area-based models were developed using the full set of LiDAR metrics as predictors (Table S1). The $m$ try parameter in randomForest was set to $p / 3$, where $p$ is the total number of predictors used. Area-based models for merchantable basal area, merchantable stem volume, and gross total volume (merchantable stems), used predictions of ratios to constrain the final predictions to ensure they were logical (e.g., gross total volume for all stems is always equal to or greater than predictions of gross total volume of merchantable stems). Ratios of volume to basal area (VBAR TVOL_ratio, VBAR_MVOL_ratio, and BA_merch_ratio) were calculated as indicated in Table 4 . Using these ratios, TVOL_merch, MVOL, and BA_merch were calculated as indicated in Table 5.

\section{Measures of model performance}

Measures of model performance included bias and the root mean squared error (RMSE). Relative bias and RMSE were also calculated, using the mean of the observed values for each forest type.
Bias is the difference between the observed and predicted attribute and the average bias was calculated as follows:

$$
\text { Bias }=\frac{\sum\left(Y_{\text {obs }}-Y_{\text {pred }}\right)}{n}
$$

The root mean squared error (RMSE) is another measure of the goodness of the predictions and was calculated as follows:

$$
R M S E=\sqrt{\frac{\sum\left(Y_{\text {obs }}-Y_{\text {pred }}\right)^{2}}{n}}
$$

The relative bias (Bias\%) and RMSE (RMSE\%) were calculated relative to the mean of the observed values as follows:

$$
\begin{aligned}
& \text { Bias } \%=\frac{\text { Bias }}{\operatorname{mean}\left(Y_{o b s}\right)} \times 100 \\
& R M S E \%=\frac{R M S E}{\operatorname{mean}\left(Y_{o b s}\right)} \times 100
\end{aligned}
$$




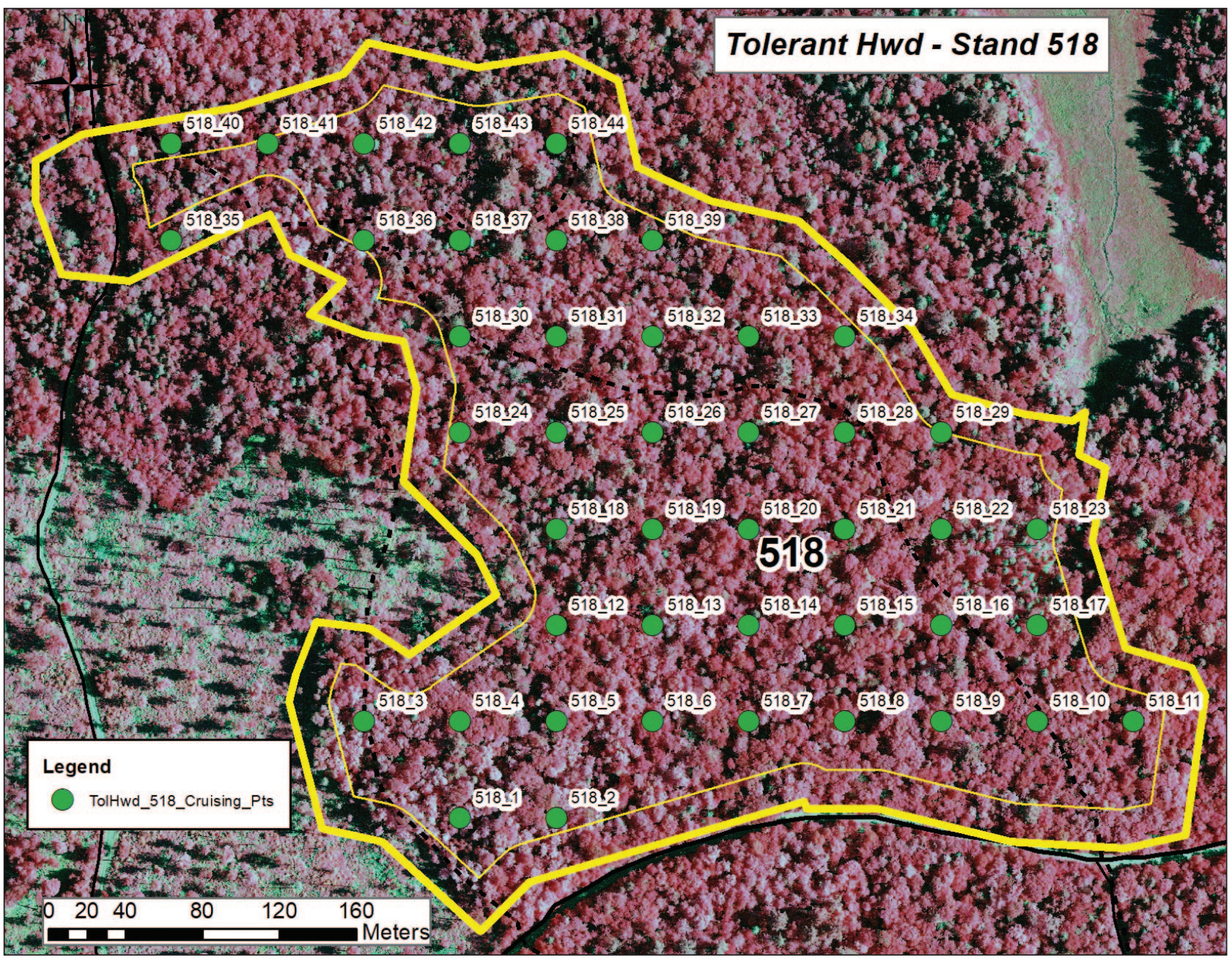

Fig. 3 Example of a 50 m grid of stations super-imposed on validation stand 518 (tolerant hardwood). An internal buffer of $12.5 \mathrm{~m}$ was used to remove stations from the stand boundary (yellow)

\section{Results}

Area-based models developed at the plot-level using the SPL data and the co-located ground plots were applied across the study area to generate wall-to-wall estimates of forest inventory attributes (Fig. 5).

\section{Ground plot validation results}

The predict function in the randomForest $R$ package was used to obtain out-of-bag (OOB) errors of model performance for the calibration plots. The OOB is a form of internal cross validation generated using hold-out sets of the calibration data (White et al. 2017). While OOB error provides an indication of model performance for the calibration plots, independent validation data at the management scale (i.e., the forest stand) is preferable for validating an area-based inventory (Gobakken et al. 2015). OOB results for calibration plots are summarized in Tables S2 and S3. For all forest types combined, relative RMSE ranged from a low of $10.15 \%$ for Lorey's height for all stems (HL_all) to a high of $29.90 \%$ for quadratic mean DBH for all stems (DQ_all), and relative bias ranged from $-1.07 \%$ for DQ_all to $0.49 \%$ for average height of dom- inant/codominant trees (CD_ht) (Table S2). For attributes that were also validated at the stand level, RMSE\% ranged from a low of $9.40 \%$ for top height (TOPHT) to a high of $33.70 \%$ for merchantable stem volume (MVOL), and relative bias ranged from $-0.21 \%$ for gross total volume of merchantable stems (TVOL_merch) to $1.20 \%$ for MVOL. Model performance varied by forest type, with oak, natural pine, and mixedwood stands consistently having the largest model OOB RMSE\% (Table S3). In summary, the OOB errors indicate that volume and basal area were more challenging to estimate than height attributes, and that certain forest types tended to have larger errors, namely oak, pine natural, and mixedwood forest types.

\section{Stand-level validation results}

Independent validation data (Table 3) were used to assess stand-level estimates of key forest inventory attributes. Overall, for all forest types combined, the area-based models generated with the SPL data had small relative RMSE (RMSE\%) ranging from $7.24 \%$ for Lorey's height for merchantable stems (HL_merch) to $16.27 \%$ for MVOL (Fig. 6; Table S4). 


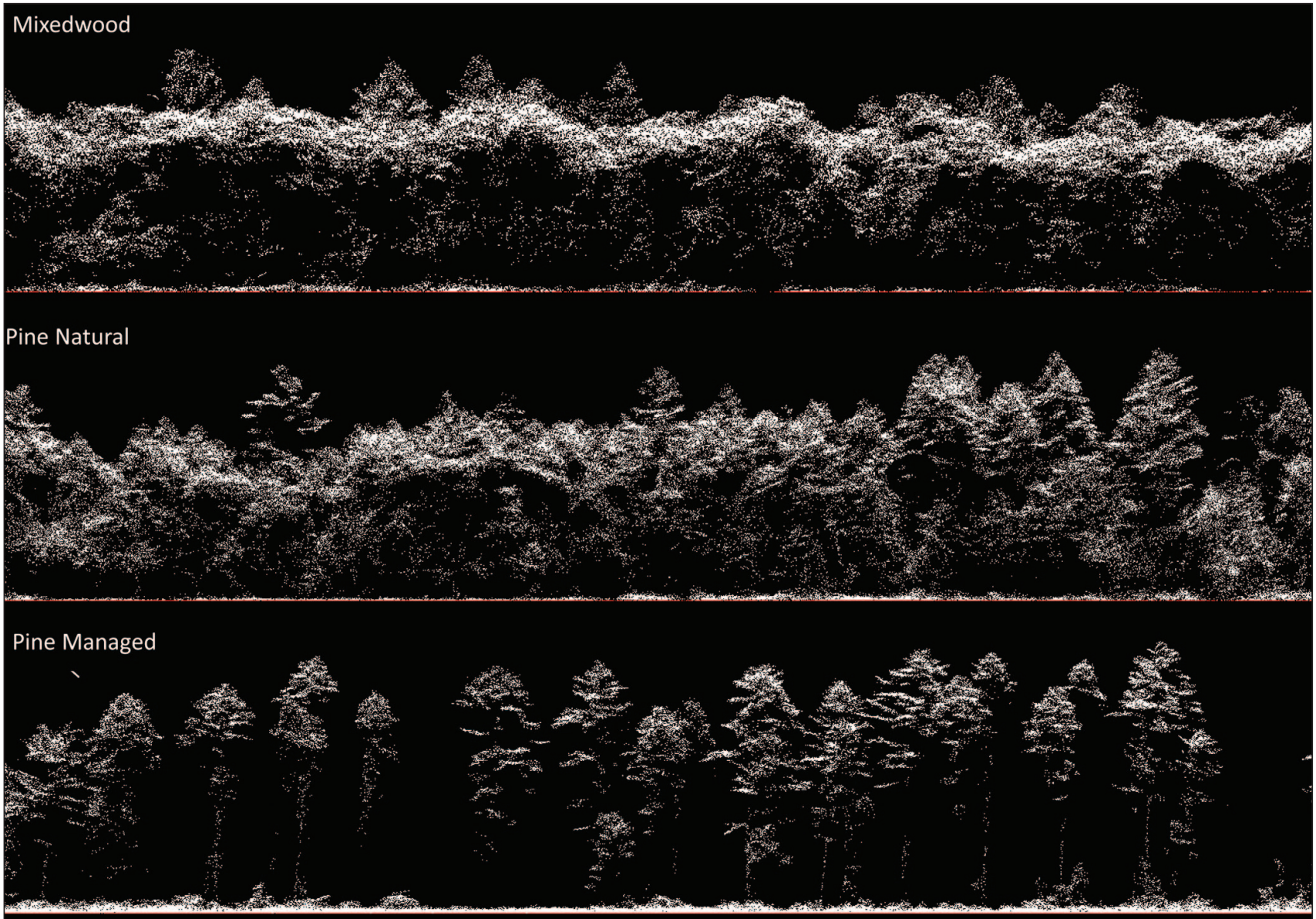

\section{Red Pine Plantation}

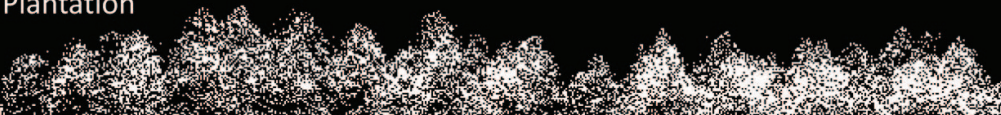

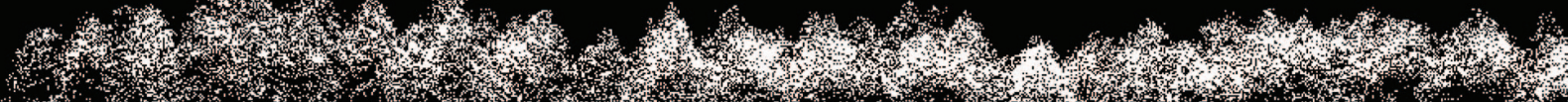

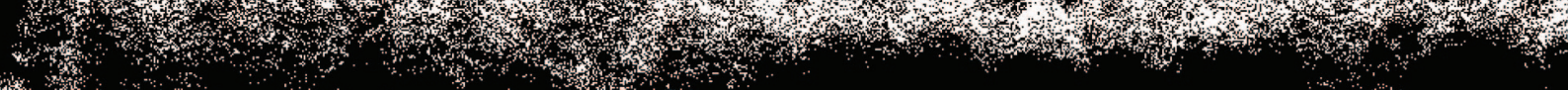

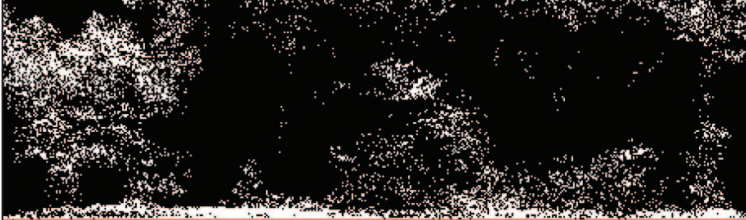

Jack Pine

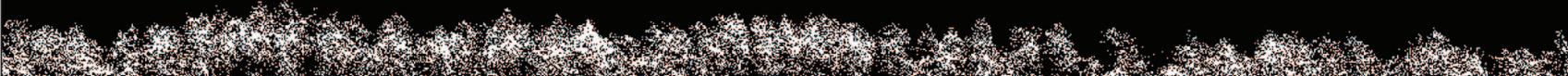

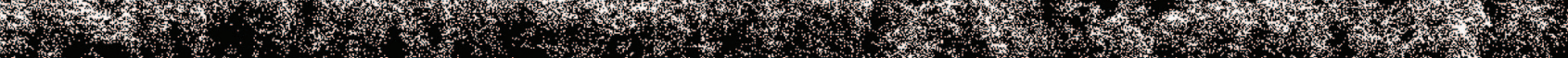
(1.

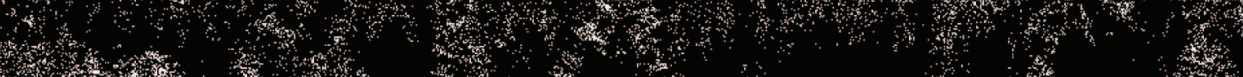
7.

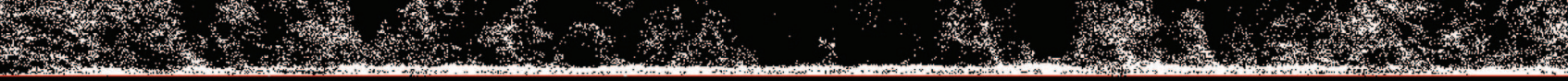

Fig. 4 SPL profiles of selected forest types within the study area 
Table 4. Forest inventory attributes directly predicted in area-based models; note that merchantable attributes were only predicted when the $99^{\text {th }}$ percentile of LiDAR point cloud heights (P99) was greater than $5 \mathrm{~m}$

\begin{tabular}{lll}
\hline Attribute & Definition & Size \\
\hline TOPHT & top height (average height of thickest 6 trees/plot) $(\mathrm{m})$ & $\mathrm{DBH} \geq 2.5 \mathrm{~cm}$ \\
HL_all & Lorey's height (average height weighted by BA) $(\mathrm{m})$ & $\mathrm{DBH} \geq 2.5 \mathrm{~cm}$ \\
CD_ht & average height of dominant/codominant trees $(\mathrm{m})$ & $\mathrm{DBH} \geq 2.5 \mathrm{~cm}$ \\
DQ_all & quadratic mean DBH, all stems $(\mathrm{cm})$ & $\mathrm{DBH} \geq 2.5 \mathrm{~cm}$ \\
BA_all & basal area, all stems $\left(\mathrm{m}^{2} / \mathrm{ha}\right)$ & $\mathrm{DBH} \geq 2.5 \mathrm{~cm}$ \\
TVOL_all & gross total volume, all stems $\left(\mathrm{m}^{3} / \mathrm{ha}\right)$ & $\mathrm{DBH} \geq 2.5 \mathrm{~cm}$ \\
BIO_all & aboveground biomass, all stems $(\mathrm{kg} / \mathrm{ha})$ & $\mathrm{DBH} \geq 2.5 \mathrm{~cm}$ \\
DQ_merch & quadratic mean DBH, merchantable stems $(\mathrm{cm})$ & $\mathrm{DBH} \geq 9.1 \mathrm{~cm}$ \\
VBAR_TVOL & TVOL_all/BA_all & $\mathrm{DBH} \geq 2.5 \mathrm{~cm}$ \\
VBAR_TVOL_merch & TVOL_merch/BA_merch & $\mathrm{DBH} \geq 9.1 \mathrm{~cm}$ \\
VBAR_TVOL_ratio & VBAR_TVOL_merch/VBAR_TVOL & $\mathrm{DBH} \geq 9.1 \mathrm{~cm}$ \\
VBAR_MVOL & MVOL/BA_merch & $\mathrm{DBH} \geq 9.1 \mathrm{~cm}$ \\
VBAR_MVOL_ratio & VBAR_MVOL/VBAR_TVOL_merch & $\mathrm{DBH} \geq 9.1 \mathrm{~cm}$ \\
BA_merch_ratio & BA_merch/BA_all & $\mathrm{DBH} \geq 9.1 \mathrm{~cm}$ \\
HL_merch_ratio & HL_merch/HL_all & $\mathrm{DBH} \geq 9.1 \mathrm{~cm}$ \\
BIO_merch_ratio & BIO_merch/BIO_all & $\mathrm{DBH} \geq 9.1 \mathrm{~cm}$ \\
\hline
\end{tabular}

The performance of attribute estimates varied by forest type, with managed pine stands typically having the largest relative bias and RMSE of all forest types considered. At the stand level, TOPHT was underestimated by an average of $10.34 \%$, with an overall RMSE of $13.52 \%$. Based on the three managed pine stands used for validation, this forest type had the largest relative bias (21.18\%) and RMSE (22.40\%) for TOPHT. In contrast, jack pine stands had the lowest relative RMSE $(2.37 \%)$ and bias $(-1.98 \%)$, with TOPHT of jack pine stands overestimated by an average of $-0.44 \mathrm{~m}$. By definition, TOPHT represents the average height of the thickest 100 trees/ha. For the calibration data, TOPHT was the average height of the six thickest trees in the plot (equalling 100 trees/ha; Table 4). However, for the validation data, only the largest tree at each prism station was measured for TOPHT. These differences in field protocols resulted in larger biases for TOPHT, compared to bias associated with other attributes (Fig. 6). In some forest types, it is a common management practice to leave a few large trees in the stand following harvesting, particularly in managed and natural pine stands, and in mixedwood stands. When measuring height from the LiDAR data, the heights of these tall trees are combined with the heights of the shorter trees, thereby lowering top height estimates in these forest types.

Predictions of TVOL_merch were relatively unbiased for all forest types combined $(0.39 \%)$ with a relative RMSE of $14.61 \%$. Bias for TVOL_merch varied by forest type, with TVOL_merch overestimated for managed pine stands ($23.90 \%)$. These are tall stands, with a mean height of $25 \mathrm{~m}$, within which some of the overstorey trees have been removed to encourage growth of residual stems and establish regener- ation (Fig. 4). These stands have a relatively low volume to height ratio compared to the other forest types, leading to an overestimation of TVOL_merch by $\sim 41 \mathrm{~m}^{3} /$ ha on average (Table S4; Fig. 7). TVOL_merch was also overestimated in poplar stands, which had a negative bias of $-13.27 \%$. This overestimation may be a function of data compilation: ground estimates of volume use individual tree taper models, which work well for single straight tree stems; however hardwood tree species such as poplar often have significant branching that confounds the definition and measurement of the main stem volume. In contrast, mature red pine plantations tend to have less vertical complexity and larger volumes and basal area. TVOL_merch was underestimated in red pine plantations by $17.77 \%$, and basal area for merchantable stems (BA_merch) was underestimated by $19.84 \%$ (Table S4). Compared to other forest types, the red pine plantations tended to have lower average plot heights estimated from the SPL data at relatively high estimates of TVOL_merch (Fig. 7), with lower estimates of cover from the SPL data relative to basal area measured at the field plots (Fig. 8).

Results for MVOL for all forest types combined indicated an overall relative bias of $3.37 \%$ and a relative RMSE of $16.27 \%$ (Fig. 6). Similar to results for TVOL_merch, MVOL was overestimated for pine managed $(-23.90 \%)$ and poplar stands $(-13.27 \%)$, and underestimated for lowland conifer (24.84\%) and red pine plantation stands (19.47\%).

For all forest types combined, relative bias for BA_merch was small (1.68\%) and relative RMSE was $14.42 \%$ (Fig. 6). Similar to volume attributes, BA_merch was overestimated in pine managed $(-22.50 \%)$ and poplar $(-17.88 \%)$ stands, and underestimated in lowland conifer $(29.63 \%)$ and mature red 
Table 5. Forest inventory attributes that are not predicted directly from SPL data, but rather derived from other attributes (i.e., from those listed in Table 4]

\begin{tabular}{|c|c|c|c|}
\hline Attribute & Definition & Size & Calculation \\
\hline TPH_all & stems/ha, all stems & All & BA_all/ (DQ_all*DQ_all $\left.{ }^{*} 0.00007854\right)$ \\
\hline HL_merch & Lorey's height, merchantable stems (m) & $\mathrm{DBH} \geq 9.1 \mathrm{~cm}$ & HL_all ${ }^{\star} H L \_m e r c h \_r a t i o$ \\
\hline BA_merch & basal area, merchantable stems $\left(\mathrm{m}^{2} / \mathrm{ha}\right)$ & $\mathrm{DBH} \geq 9.1 \mathrm{~cm}$ & BA_all ${ }^{*}$ BA_merch_ratio \\
\hline TPH_merch & stems/ha, merchantable stems & $\mathrm{DBH} \geq 9.1 \mathrm{~cm}$ & $\begin{array}{l}\text { BA_merch/DQ_merch }{ }^{*} \\
\left.\text { DQ_merch }{ }^{*} 0.00007854\right)\end{array}$ \\
\hline TVOL_merch & gross total volume, merchantable stems $\left(\mathrm{m}^{3} / \mathrm{ha}\right)$ & $\mathrm{DBH} \geq 9.1 \mathrm{~cm}$ & $\begin{array}{l}\text { TVOL_allVBAR_TVOL_ratio* } \\
\text { BA_merch_ratio }\end{array}$ \\
\hline BIO_merch & aboveground biomass, merchantable stems (kg/ha) & $\mathrm{DBH} \geq 9.1 \mathrm{~cm}$ & BIO_all*BIO_merch_ratio \\
\hline MVOL & merchantable stem volume $\left(\mathrm{m}^{3} / \mathrm{ha}\right)$ & $\mathrm{DBH} \geq 9.1 \mathrm{~cm}$ & TVOL_merch*VBAR_MVOL_ratio \\
\hline
\end{tabular}

pine plantations (19.84\%). Largest relative RMSE for BA_merch was associated with lowland conifer (29.6\%), managed pine $(24.09 \%)$, and red pine plantations $(22.27 \%)$. Different forest types have different relationships between SPL estimates of canopy cover and BA_merch. As indicated in Fig. 8, red pine plantations can have larger BA_merch values at moderate levels of cover, whereas managed pine or mixedwood stands can have relatively high cover at low BA_merch.

Estimates for DQ_merch followed similar patterns to those of the other attributes, with largest relative RMSE for poplar $(21.00 \%)$, red pine plantations $(16.28 \%)$, and managed pine stands (15.02\%). Of note, the magnitude of the estimation error and bias was markedly lower for DQ_merch relative to the other attributes validated at the stand level (Fig. 6).

\section{Discussion}

To quantify the performance of SPL data in an area-based approach to predicting forest inventory attributes, we developed area-based models for a suite of forest inventory attributes using SPL data acquired in July 2018, and colocated ground plot data. We quantified the accuracy of the resulting forest inventory attribute predictions using independent, stand-level validation data. Overall for all forest types, we found that the area-based models generated using the SPL data produced accurate predictions of our forest inventory attributes of interest, with minimal bias; however both accuracy and bias varied by forest type. Certain forest types were more challenging to model as a function of multiple layers or cohorts in the stands (Fig. 4). As a transition zone between conifer-dominated boreal forests to the north and deciduous-dominated temperate forests to the south, our study area in the Great Lakes-St. Lawrence forest region represents a diverse range of forest conditions, with complex assemblages of species and forest management histories. These represent more challenging conditions for area-based modelling than are typically experienced in boreal forest conditions (Woods et al. 2011), which to date has been the primary geographic focus for the assessment of SPL technology for forest inventory (Wästlund et al. 2018, Yu et al. 2020).
Comparisons of the model performance reported herein with that of other published studies are challenging given the different plot sizes and validation approaches used. Overall, estimation errors from our stand-level validation are comparable to those of Wästlund et al. (2018), who used SPL100 data to estimate inventory attributes for 184 pine and spruce dominated plots (plot size $=78 \mathrm{~m}^{2}$ ) in southern Sweden. Our relative RMSE for Lorey's mean height was larger; however our overall relative RMSE for basal area, quadratic mean diameter, volume, and aboveground biomass, were lower than those reported in Wästlund et al. (2018), (Table 6). Our OOB estimation errors at the plot level (Tables S2 and S3) were generally larger than those reported by Yu et al. (2020) who used SPL100 data to estimate inventory attributes for 87 spruce, pine, and birch plots (plot size $=1024 \mathrm{~m}^{2}$ ) in southern Finland, which is likely a function of the more complex forest composition at the study site used herein.

Wästlund et al. (2018) also compared the performance of the SPL100 to that of the Optech Titan, and posited that the Titan estimate of canopy cover (defined as the proportion of first returns $>1.5 \mathrm{~m}$ ) saturated earlier relative to that of the SPL100; however, the authors disregarded differences in leafon (Titan) and leaf-off (SPL100) acquisition conditions between these data in their assessment. The results of Yu et al. (2020), which also compared SPL100 and Optech Titan data (both leaf-on acquisitions), indicate that estimates of canopy volume (i.e. mean height multiplied by the ratio of vegetation returns) are larger from the Optech Titan data relative to the SPL data, but that differences between the two data sources in estimates of cover vary through the vertical profile of the canopy and are minimized at the top of canopy. SPL100 data are known to acquire fewer returns for each emitted LiDAR pulse, with only 1.06 returns through dense vegetation for SPL100 compared to 1.84 returns from full waveform systems (Mandleburger et al. 2019). In addition, the range resolution of the SPL100 is known to be considerably lower (10 $\mathrm{m})$ than that of the Optech Titan $(4.3 \mathrm{~m})$. Brown et al. (2020) demonstrated that the SPL100 range resolution is limited primarily by noise filtering, and other authors have likewise posited that the lack of intermediate returns in SPL data is 


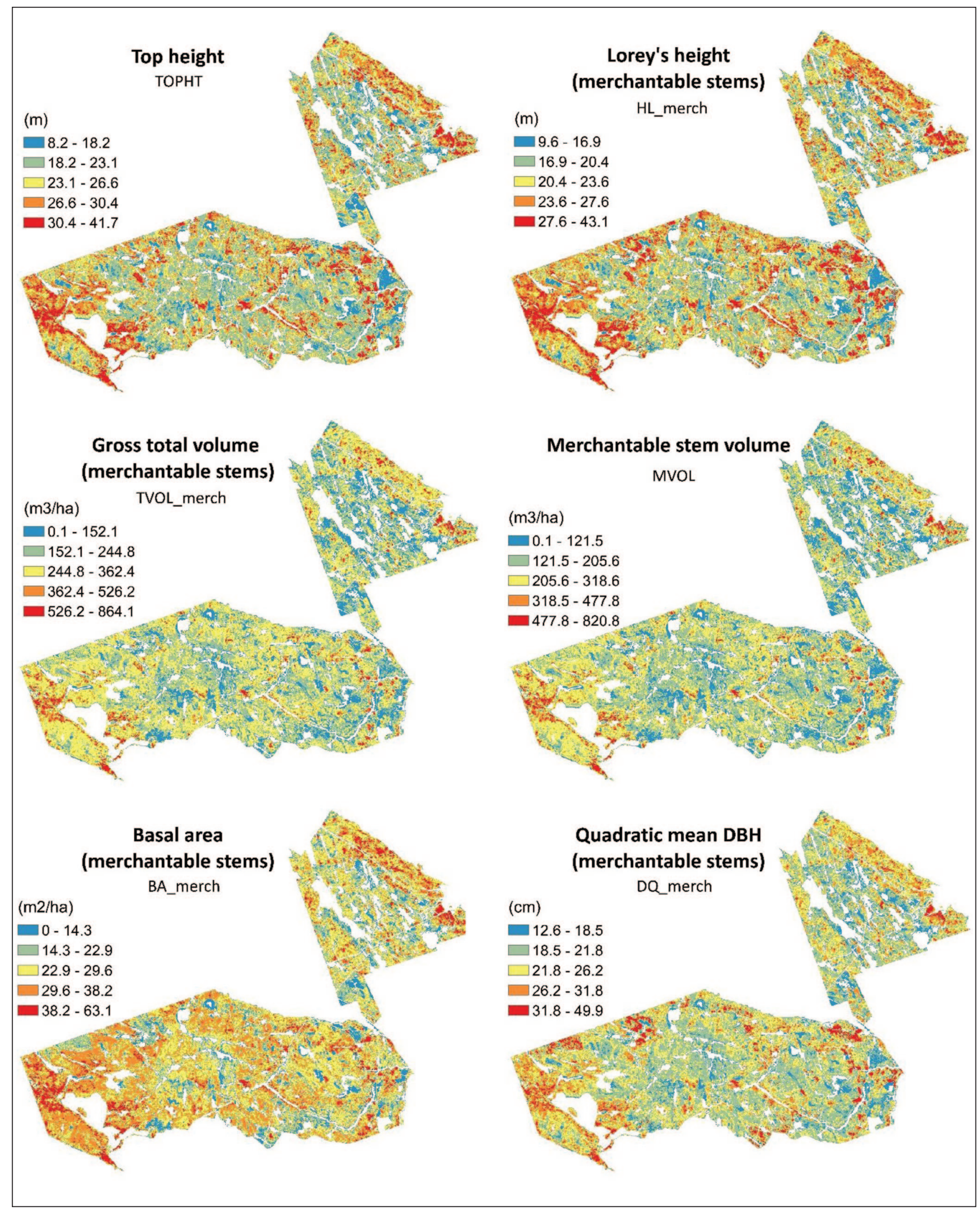

Fig. 5 Wall-to-wall area-based predictions of select forest inventory attributes for the PRF and CNL lands. Attributes shown were validated at the stand level using independent reference data 


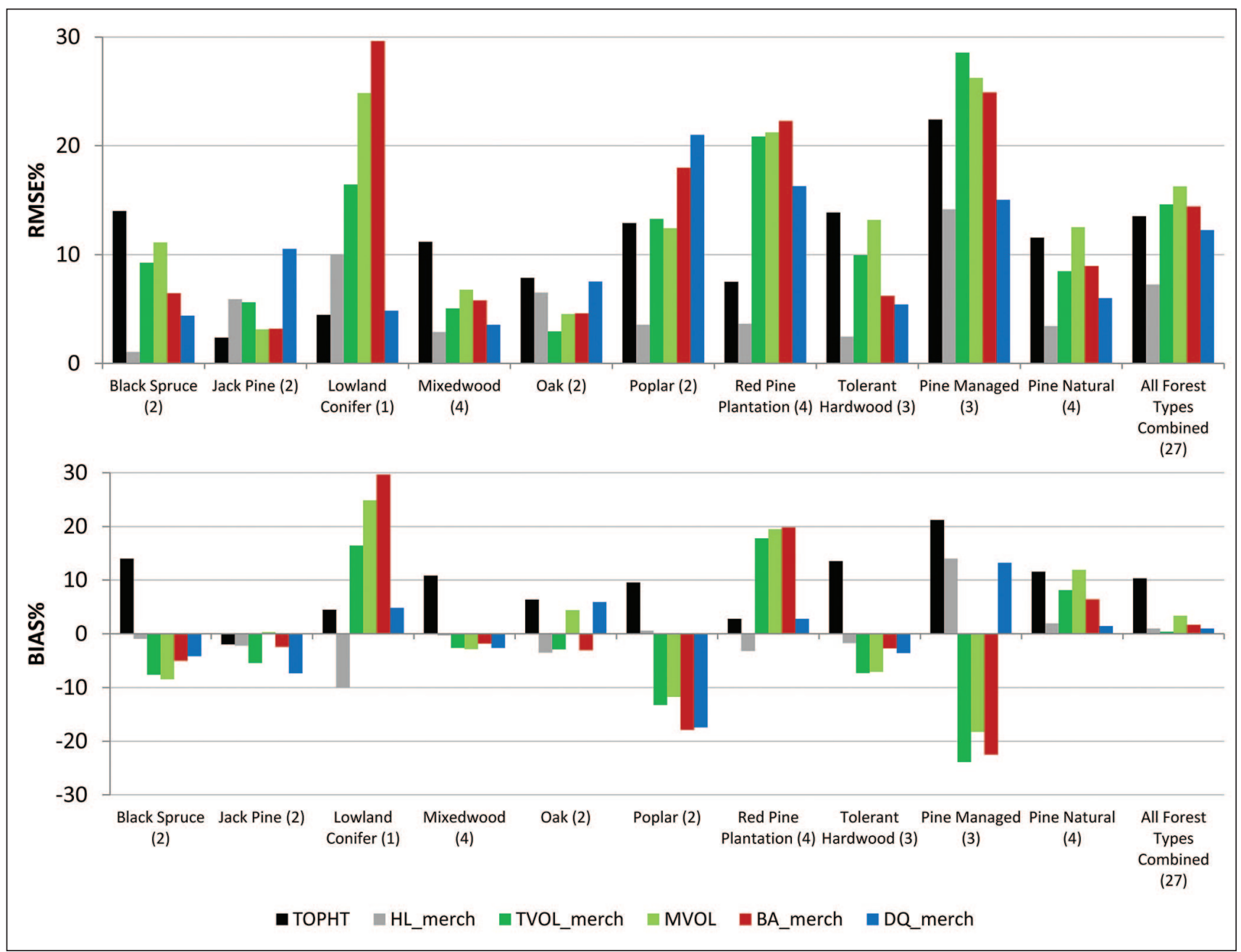

Fig. 6 Relative RMSE and bias, by forest type, for stand-level validation data of predicted forest inventory attributes. The number of validation stands associated with each forest type is included in parentheses

Table 6. Relative RMSE\% for forest inventory attribute models as reported in Wästlund et al. (2018), Yu et al. (2020) and this study

\begin{tabular}{lcccc}
\hline & Wästlund et al. (2020) & Yu et al. (2020) & This study & This study \\
Forest inventory attribute & $\begin{array}{c}\text { Leave-one-out } \\
\text { cross validation } \\
\text { at the plot level }\end{array}$ & $\begin{array}{c}\text { Random forests out } \\
\text { of-bag error at the } \\
\text { plot level }\end{array}$ & $\begin{array}{c}\text { Independent } \\
\text { stand-level } \\
\text { validation data }\end{array}$ & $\begin{array}{c}\text { Random forests out- } \\
\text { of-bag error at the } \\
\text { plot level }\end{array}$ \\
\hline Lorey's height & $6.11 \%$ & $6.73 \%$ & $7.24 \%$ & $10.15 \%$ \\
Basal area & $21.98 \%$ & $\mathrm{n} / \mathrm{a}$ & $14.42 \%$ & $26.18 \%$ \\
Quadratic mean diameter & $13.77 \%$ & $14.17 \%$ & $11.72 \%$ & $22.11 \%$ \\
Total volume & $21.23 \%$ & $16.81 \%$ & $14.61 \%$ & $30.21 \%$ \\
Aboveground biomass & $21.27 \%$ & $15.79 \%$ & $11.72 \%$ & $25.05 \%$ \\
\hline
\end{tabular}




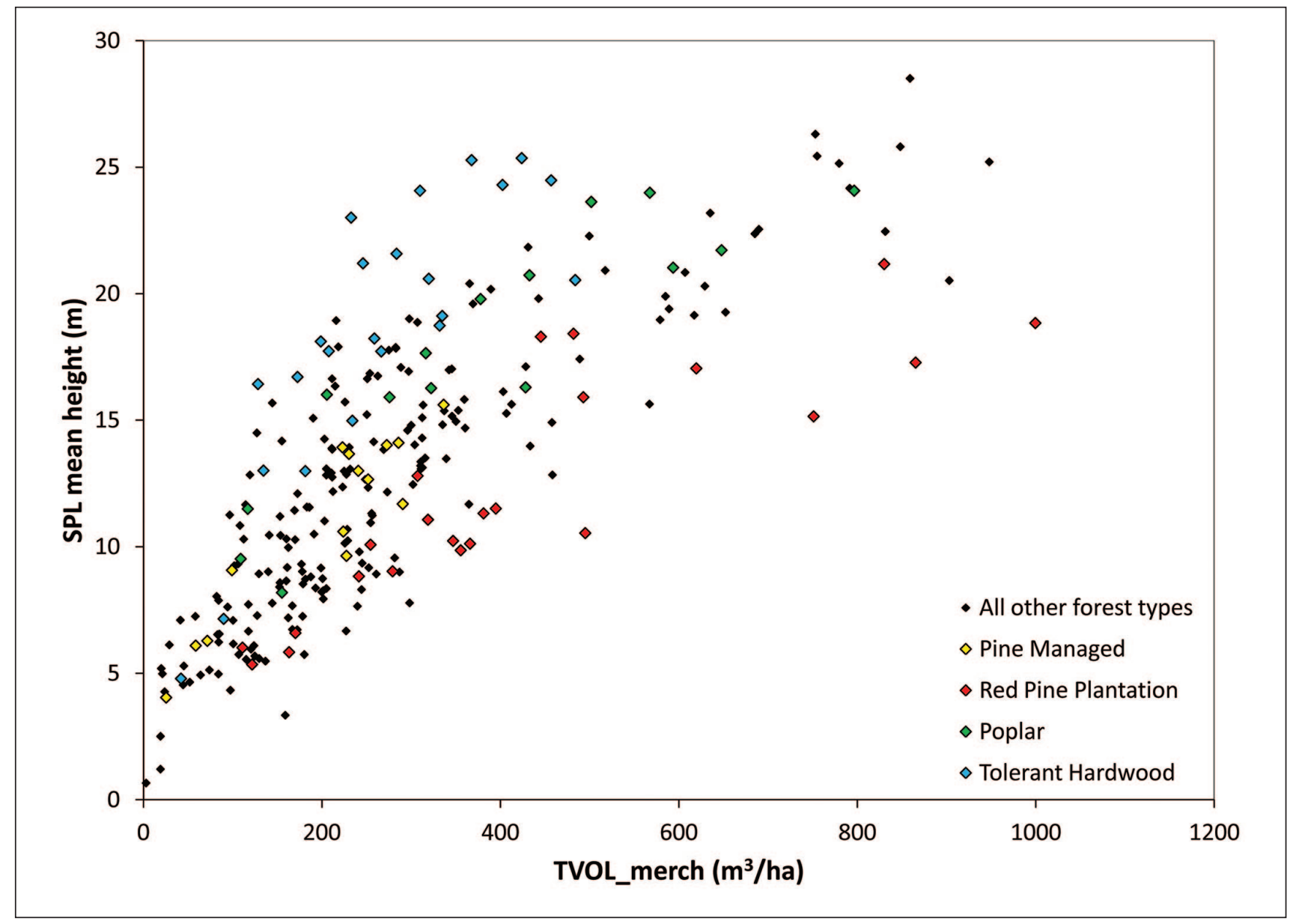

Fig. 7 Gross total volume for merchantable stems (TVOL_merch) plotted against the mean height of the SPL returns for the calibration plots

likely a function of aggressive noise filtering (Li et al. 2016; Stoker et al. 2016; Brown et al. 2020). For the SPL100 data used herein, $88 \%$ of the returns in the SPL data were first returns and the ratio of first returns to second returns was 8.8. We found that SPL estimates of cover (defined as percentage of SPL first returns $>2 \mathrm{~m}$ ) saturated at relatively low basal area for certain forest types (e.g., mixedwood), whereas other forest types exhibited different relationships between basal area and estimates of canopy cover (Fig. 8), depending on the configuration of vegetation through the vertical profile (e.g., red pine plantations; Fig. 4).

Swatantran et al. (2016) was one of the first studies to assess SPL data for forest structure characterization, comparing canopy height measurements from the HRQLS SPL data (a precursor to the SPL100) to a low-density $\left(<1 \mathrm{pulse} / \mathrm{m}^{2}\right)$ leaf-off LML dataset. The authors conducted their study in a temperate forest in Maryland dominated by oaks, northern hardwoods, hemlock, and pine. Using 71 variable radius plots acquired contemporaneously with the SPL data, and in which the two or three tallest trees on each plot were measured for height, the authors reported that the HRQLS had an RMSE of $5.42 \mathrm{~m}$ for plot height (bias $=1.2 \mathrm{~m}$ ), whereas the LML had an RMSE of $5.37 \mathrm{~m}$ (bias $=-0.26 \mathrm{~m}$ ). Swatantran et al. (2016) also reported that agreement between SPL and
LML height percentiles were stronger at the canopy surface (maximum height; RMSE $=3.85 \mathrm{~m}$ ) than further down within the canopy $\left(25^{\text {th }}\right.$ percentile of height; $\left.\mathrm{RMSE}=6.09 \mathrm{~m}\right)$. In contrast to these results, herein we report markedly lower errors for height estimates using the SPL100 at both the plot and the stand level. For the calibration plots, TOPHT OOB error was $2.3 \mathrm{~m}(9.40 \%)$ with a bias of $0.09 \mathrm{~m}(0.37 \%$; Table S3), and HL OOB error was $2.2 \mathrm{~m}$ (10.15\%) with a bias of 0.06 $\mathrm{m}(0.27 \%$, Table S3). At the stand level, HL RMSE was 1.61 $\mathrm{m}(7.24 \%)$ with a bias of $0.22 \mathrm{~m}(0.97 \%$; Table S4). We attribute the differences between our results and those of Swatantran et al. (2016) to our use of data from improved SPL sensors (SPL100 versus HRQLS) and our use of fixedarea plots rather than variable radius plots, the latter of which are notably more difficult for geolocation and comparison to the LiDAR (White et al. 2013).

Area-based models are often validated at the plot level, either using reserved or independent sets of plot data or via cross-validation approaches whereby subsets of data are iteratively withheld from model development and used for validation (White et al. 2016). Approaches using random forests will also generate an out-of-bag error as an indication of model performance. While these various validation approaches may be acceptable from a scientific perspective, 


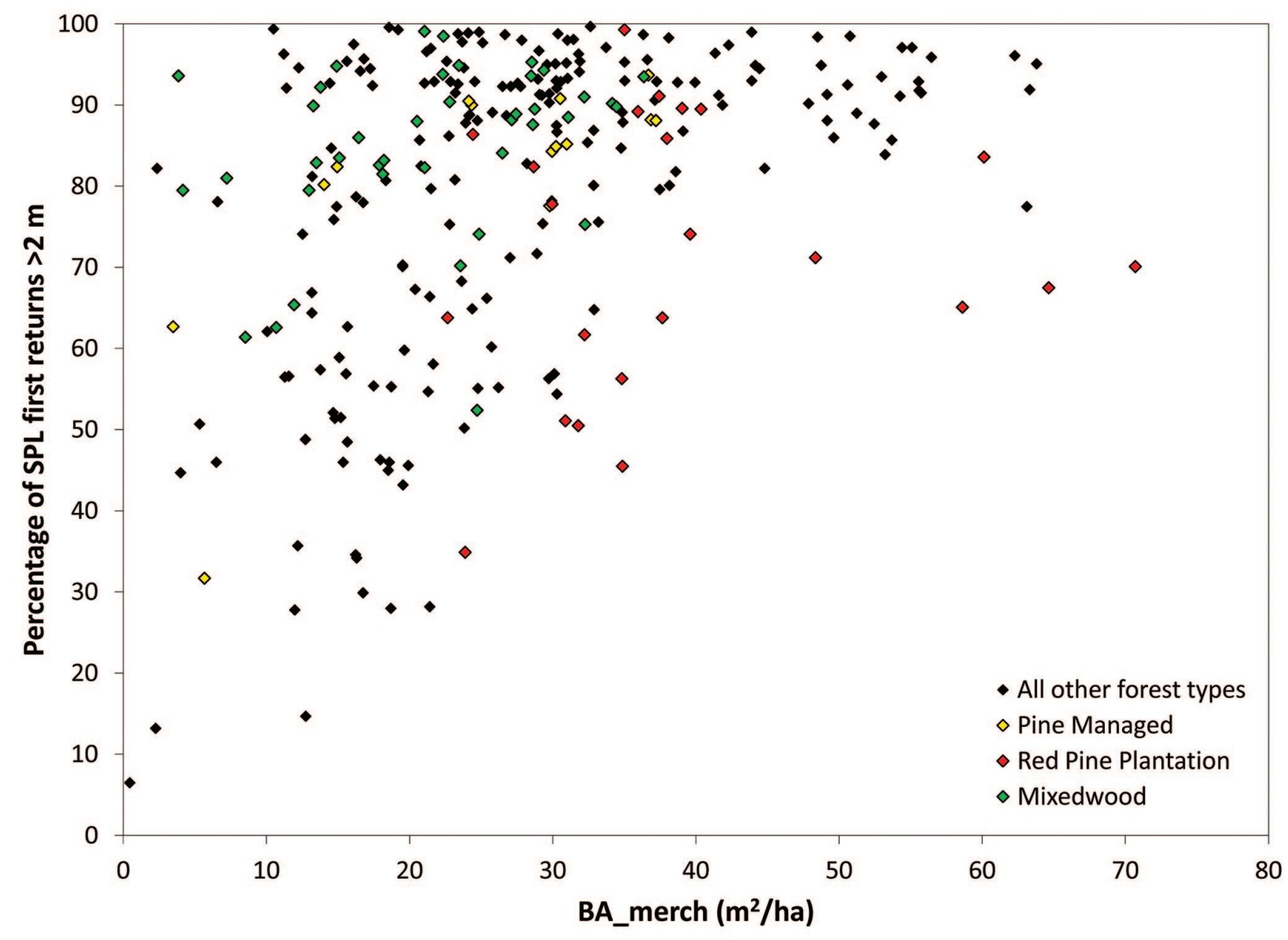

Fig. 8 Basal area for merchantable stems (BA_merch) plotted against the SPL estimate of canopy cover (the percentage of SPL returns that are $>2 \mathrm{~m}$ )

they do not provide an assessment of model performance for the unit of interest for management - that being the forest stand, which is commonly the fundamental unit used for both forest management and planning. The stand-level sampling applied herein for validation is labour intensive; however, it enables validation of attributes at the spatial unit that is most relevant for the application of these data (Gobakken et al. 2015). Herein, we reported both plot-level OOB error (Tables S2 and S3) and independent stand-level validation results (Fig. 6, Table S4). Overall for all forest types combined, plot-level OOB overestimated model error and underestimated bias (Table S3) relative to the stand-level validation results (Fig. 6, Table S4). Both sources of validation data indicated that model performance varied among different forest types and that particular stand types were more challenging to accurately predict (i.e., red pine plantations). The OOB did not highlight issues in model performance for pine managed stands to the same degree as the stand-level validation. This result underscores how area-based models can be challenged by both forest structures that may be outliers in the range of variability of structure assessed in the calibration data (e.g., red pine plantations, see Figs. 4, 7, and 8), as well as by the spatial manifestation of model errors that may increase in forest types that have substantial spatial heterogeneity in vertical structures (e.g., managed pine stands). It is worth noting that shelterwood silvicultural systems commonly represent $<$ $10 \%$ of the total area harvested in Ontario each year (Ontario Ministry of Natural Resources and Forestry 2015).

TOPHT was the most challenging attribute to predict accurately, regardless of forest type. As noted earlier, measurement approaches for TOPHT calibration and validation data were not identical, which undoubtedly contributed uncertainty to the assessments of TOPHT model performance. A challenge for estimating TOPHT is having an adequate sample of trees to enable top height calculation at the plot level. Moreover, the degree to which the sample used for the calculation of top height at the plot-level is also representative of stand-level height distributions varies considerably, and this is influenced by management histories. For example, in a stand that is being managed as a uniform shelterwood, TOPHT will be biased by taller trees that are retained in the stand as a seed source. Conversely, taller trees may be removed from a stand to increase crown spacing and light availability, resulting in shorter trees being included to estimate TOPHT (Woods et al. 2008). Overall, RMSE for TOPHT reported herein was $3.58 \mathrm{~m}$ (13.52\%), which is larger 


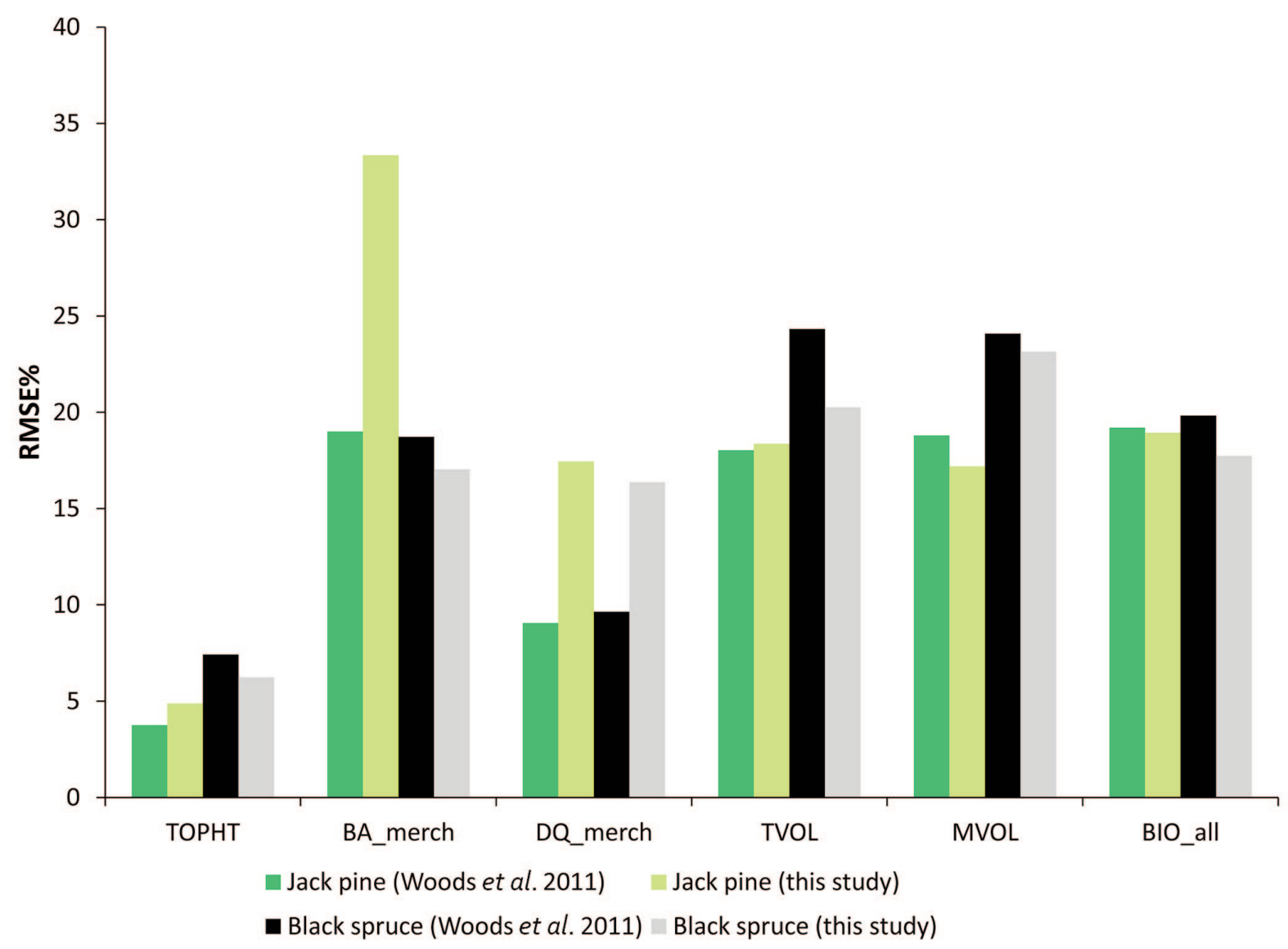

Fig. 9 Relative RMSE for area-based forest inventory attributes generated from this study and as reported in Woods et al. (2011); for both studies, values are reported for calibration plots

than that reported by Woods et al. (2008) in similar forest types using discrete return LiDAR (RMSE $=0.65 \mathrm{~m}-0.89 \mathrm{~m}$; RMSE\% $=3-4 \%$ ).

While comparisons to predictions generated from contemporaneous LML data in our study area were not possible, comparisons can be made to past studies reporting areabased results in the same forest type. Overall, RMSE for BA_merch was $3.78 \mathrm{~m}^{2} / \mathrm{ha}(14.42 \%)$ and these results are lower than those previously reported by Woods et al. (2008) in similar forest types, with RMSE values ranging from 3.46 $\mathrm{m}^{2} /$ ha $(17.0 \%)$ to $7.23 \mathrm{~m}^{2} /$ ha $(23.0 \%)$. Likewise, results for volume reported herein were also lower than those reported by Woods et al. (2008), with an RMSE of $36.02 \mathrm{~m}^{3} / \mathrm{ha}$ (14.61\%) reported in this study, compared to RMSE that ranged from $39.4 \mathrm{~m}^{3} /$ ha $(22.0 \%)$ to $73.0 \mathrm{~m}^{3} /$ ha $(23.0 \%)$. Attributes such as volume and basal area were most challenging in managed pine stands and red pine plantations. These challenges were evident in both the plot-level OOB error and in the stand-level validation. In the range of stand conditions included in this study, managed pine and red pine plantations represent very different stand conditions (as indicated in SPL profiles in Fig. 4). Stand-level validation data by forest type allows for improved understanding of how the devel- oped area-based models perform under different stand conditions. In our study area, forest types represent not only different tree species assemblages, but also different management histories. As a research forest and relatively small area in a forest management context, species and management histories are well documented within our study area compared to other forest areas in the region. While development of models specific to each forest type could potentially improve estimates for any given forest type, in practice this would require a priori knowledge that is commonly not available to forest managers with the level of consistency and accuracy required for reliable area-based model development over large areas. Moreover, such an approach would increase the overall sampling effort required, further increasing the cost of generating the inventory.

The results presented herein quantifies the range of errors likely to be associated with different stand conditions and allows for model improvements in those forest types that are particularly challenging. Automated methods to reliably predict detailed tree species information over very large areas with LiDAR data are not currently operationally viable. While such detailed species information is not required to generate area-based forest inventories, it is necessary infor- 
mation for other aspects of forest management and planning and therefore auxiliary information on dominant species or broad forest units must currently be generated from other data sources. Herein, the results for forest types that are more commonly found in the boreal forests are notable, namely black spruce and jack pine, which had some of the lowest model errors for all the forest attributes considered (Fig. 6). The results presented herein indicate that in boreal forest types with fewer species and less complex stand conditions, SPL data can provide accurate area-based forest inventories for management that are well within errors reported using LML data in jack pine and black spruce forest types (Fig. 9; Woods et al. 2011). These conclusions are also supported by the results of Wästlund et al. (2018) and Yu et al. (2020). However, the results reported herein have also demonstrated that SPL can also be used in an area-based approach to generate accurate predictions of forest inventory attributes with minimal bias in more complex forest types with a multitude of tree species and varying management histories.

\section{Conclusion}

Overall, the level of accuracy of forest inventory attribute predictions reported herein was well within the accuracy range reported in other studies using LML data in similar forest types. Bias for predicted attributes was likewise small overall; however both the accuracy and bias of inventory attribute predictions varied by forest type. The use of intensive standlevel sampling for validation provided confidence in modeled outcomes at the stand level, which is the primary unit for forest management and planning. This novel approach also highlighted those forest types, such as managed pine, that were more challenging to estimate accurately. The advantage of SPL technology is the capacity to acquire LiDAR data over large areas efficiently. For very large forest management areas and jurisdictions, the ability to acquire data from a single instrument with a consistent specification and in a timely manner can be critical for operational implementation. Acquisition cost is also a factor, as are many other considerations that inform the selection of data to be used in a LiDAR-based forest inventory. The results of this study demonstrate that from a model performance perspective, SPL data provided accurate forest inventory attribute estimates with minimal bias in a forest environment that has varying assemblages of tree species and complex forest management histories.

\section{Acknowledgements}

Funding for this research was primarily provided by the Ontario Forestry Futures Trust (KTTD 5B-2018). We are also grateful to our project partners who provided financial and technical support to this project: Canadian Institute of Forestry, Canadian Nuclear Laboratories, Canada Centre for Mapping and Earth Observation, and the Canadian Wood Fibre Centre of the Canadian Forest Service. We also sincerely thank Jordan MacMillan, Brian Batchelor, Melissa Vekeman, Peter Arbour, Kyle Harbin, Annie Morin, and all the field crews for technical assistance and acquisition of the calibration and validation data used in our analyses.

\section{References}

Breiman, L. 2001. Random forests. Machine Learning 45(1): 5-32. Brown, R., P. Hartzell and C. Glennie. 2020. Evaluation of SPL100 single photon lidar data. Remote Sens. 12 (4): 722. DOI: 0.3390/ rs12040722.

D’Eon, S. 2006. "20 Year results, you're just getting started” Long term experimentation at the Petawawa Research Forest: A brief introduction to a living laboratory. In: Irland, L.C., Camp, A.E., Brissette, J.C., Donohew, Z.R. (Eds.), Long-term Silvicultural and Ecological studies: Results for Science and Management. Yale University, School of Forestry and Environmental Studies, Global Institute of Sustainable Forestry Research Paper 005, pp. 128-135.

Eitel, J.U.H., B. Hoffle, L.A. Vierling, A. Abellan, G.P. Asner, J.S. Deems, C.L. Glennie, et al. 2016. Beyond 3-D: The new spectrum of lidar applications for earth and ecological sciences. Remote Sens. Environ. 186: 372-392. DOI: 10.1016/j.rse.2016.08.018.

Gluckman, J. 2016. Design of the processing chain for a high-altitude, airborne, single-photon lidar mapping instrument. Proceedings SPIE 9832, Laser Radar Technology and Applications XXI, 983203. DOI: $10.1117 / 12.2219760$.

Gobakken, T., O.M. Bollandsäs and E. Næsset. 2015. Comparing biophysical forest characteristics estimated from photogrammetric matching of aerial images and airborne laser scanning data, Scand. J. Forest Res.: 30:1, 73-86, DOI: 10.1080/02827581.2014.961954

Hyyppä, J., X. Yu, H. Hyyppa, M. Vastaranta, M. Holopainen, A. Kukko, H. Kaartinen et al. 2012. Advances in forest inventory using airborne laser scanning. Remote Sens. 4: 1190-1207. DOI: 10.3390/rs4051190.

Isenburg, M. 2020. LAStools: LiDAR Processing Software (version 190812, academic), obtained from http://rapidlasso.com/LAStools.

Lambert, M.-C., C.-H. Ung and F. Raulier. 2005. Canadian national tree aboveground biomass equations. Can. J. For. Res. 35: 1996-2018. DOI: 10.1139/x05-112.

Li, Q., J. Degnan, T. Barrett and J. Shan. 2016. First evaluation on single photon sensitive lidar data. Photogram. Engin. Remote Sens. 82(7): 455-463. DOI: 10.14358/PERS.82.7.455.

Liaw, A. and M. Wiener (2002). Classification and Regression by randomForest. R News 2(3): 18-22.

Mandlburger, G., H. Lehner and N. Pfeifer. 2019. A comparison of single photon and full waveform lidar. ISPRS Ann. Photogram. Remote Sens. Spatial Inform. Sci. Volume IV-2/W5, 2019 ISPRS Geospatial Week 2019, 10-14 June 2019, Enschede, The Netherlands. Available online (accessed 2020-09-15): https://www.isprs-annphotogramm-remote-sens-spatial-inf-sci.net/IV-2-W5/397/2019/

Næsset, E. 2002. Predicting forest stand characteristics with airborne scanning laser using a practical two-stage procedure and field data. Remote Sens. Environ. 80(1): 88-99. DOI:10.1016/S00344257(01)00290-5.

Næsset, E. 2015. Area-based inventory in Norway - from innovations to operational reality. In: Forestry Applications of Airborne Laser Scanning, Concepts and Case Studies, edited by M. Maltamo, E. Næsset, and J. Vauhkonen. New York, NY: Springer.

Natural Resources Canada. 2020. Canadian Spatial Reference System Precise Point Poisitioning Tool: https://webapp.geod.nrcan. gc.ca/geod/tools-outils/ppp.php?locale=en

Nelson, R. 2013. How did we get here? An early history of forestry LiDAR. Canadian Journal of Remote Sensing (39): pp. S1-S12. DOI: 10.5589/m13-011.

Ontario Ministry of Natural Resources and Forestry. 2015. Harvest area. https://www.ontario.ca/page/harvest-area

Penner, M., D.G. Pitt, and M.E. Woods. 2013. Parametric versus nonparametric LiDAR models for operational forest inventory in boreal Ontario. Can. J. Remote Sens. 39(5): 426-443. DOI: $10.5589 / \mathrm{m} 13-049$. 
Penner, M., M.E. Woods and D.G. Pitt. 2015. A comparison of airborne laser scanning and image point cloud derived tree size class distribution models in boreal Ontario. Forests 2015 6: 4034-4054. DOI: $10.3390 /$ f6114034.

Place, I.C.M. 2002. 75 years of research in the woods: A history of Petawawa Forest Experiment Station and Petawawa National Forestry Institute, 1918 to 1993. General Store Publishing House, Burnstown, Ontario.

Rowe, J. S. (1972). Forest Regions of Canada. Ottawa, Ontario: Government of Canada, Department of Environment, Canadian Forestry Service, Publication No. 1300.

Sharma, M. 2016. Comparing height-diameter relationships of boreal tree species grown in plantations and natural stands. For. Sci. 62: 70-77. DOI: 10.5849/forsci.14-232.

Sharma, M. and J. Parton. 2009. Modeling stand density effects on taper for jack pine and black spruce plantations using dimensional analysis. For. Sci. 55: 268-282. DOI: 10.1093/forestscience/55.3.268. Stoker, J.M. O.A. Abdullah, A. Nayegandhi and J. Winehouse. 2016. Evaluation of single photo and geiger mode lidar for the $3 \mathrm{D}$ elevation program. Remote Sens. 8(9): 767. DOI: 10.3390/ rs8090767.

Swatantran, A., H. Tang, T. Barrett, P. DeCola and R. Dubayah. 2016. Rapid, high-resolution forest structure and terrain mapping over large areas using single photon lidar. Sci. Rep. 6: 28277. DOI: 10.1038/srep28277.

Thomas, V., P. Treitz, J.H. McCaughey and I. Morrison. 2006. Mapping stand-level forest biophysical variables for a mixedwood boreal forest using LiDAR: An examination of scanning density. Can. J. For. Res. 36: 34-47. DOI: 10.1139/x05-230.

Treitz. P., K. Lim, M. Woods, D. Pitt, D. Nesbit and D. Etheridge. 2012. LiDAR sampling density for forest resource inventories in Ontario. Remote Sens. 4: 830-848. DOI: 10.3390/rs4040830.

Wästlund, A., J. Holmgren, E. Lindberg and H. Olsson. 2018. Forest variable estimation using a high altitude single photon lidar system. Remote Sens. 10: 1422. DOI: 10.3390/rs10091422.

Wetzel, S., D.E. Swift, D. Burgess and C. Robinson. 2011. Research in Canada's National Research Forests-past, present, and future. Forest Ecol. Manag. 261: 893-899. DOI: 10.1016/j.foreco. 2010.03.020.

White, J.C., H. Chen, M.E. Woods, B. Low and S. Nasonova. 2019. The Petawawa Research Forest: Establishment of a remote sensing supersite. For. Chron. 95(3): 149-156. DOI: 10.5558/tfc2019-024.
White, J.C., N.C. Coops, M.A. Wulder, M. Vastaranta, T. Hilker and P. Tompalski. 2016. Remote sensing for enhancing forest inventories: A review. Can. J. Remote Sens. 42(5): 619-641. DOI: 10.1080/07038992.2016.1207484.

White, J.C., P. Tompalski, M. Vastaranta, M.A. Wulder, S. Saarinen, C. Stepper and N.C. Coops. 2017. A model development and application guide for generating an enhanced forest inventory using airborne laser scanning data and an area-based approach. Information Report FI-X-018, Canadian Forest Service, Canadian Wood Fibre Centre. Available online: https://cfs.nrcan.gc.ca/publications? id $=38945$

White, J.C., M. Woods, T. Krahn, C. Papasodoro, D. Belanger, C. Onafrychuk, I. Sinclair. 2021. Evaluating the capacity of single photon lidar for terrain characterization under a range of forest conditions. Remote Sensing of Environment, 252, 112169.

White, J.C., M.A. Wulder, A. Varhola, M. Vastaranta, N.C. Coops, B.D. Cook, D.F. Pitt and M. Woods. 2013. A best practices guide for generating forest inventory attributes from airborne laser scanning data using the area-based approach. Information Report FI-X-010. Canadian Forest Service. Canadian Wood Fibre Centre. Available online: http://cfs.nrcan.gc.ca/pubwarehouse/pdfs/34887.pdf Woods, M., K. Lim and P. Treitz. 2008. Predicting forest stand variables from LiDAR data in the Great Lakes-St. Lawrence forest of Ontario. For. Chron. 84(6): 827-839. DOI: 10.5558/tfc84827-6.

Woods, M., D. Pitt, M. Penner, K. Lim, D. Nesbitt, D. Etheridge and P. Treitz. 2011. Operational implementation of a LiDAR inventory in boreal Ontario. For. Chron. 87(4): 512-528. DOI: $10.5558 / \mathrm{tfc} 2011-050$

Wulder, M.A., C.W. Bater, N.C. Coops, T. Hilker and J.C. White. 2008. The role of LiDAR in sustainable forest management. For. Chron. 84: 6: 807-826. DOI: 10.5558/tfc84807-6.

Yu, X., A. Kukko, H. Kaartinen, Y. Wang, X. Liang, L. Matikainen and J. Hyyppä. 2020. Comparing features of single and multi-photon lidar in boreal forests. ISPRS J. Photogram. Remote Sens. 168: 268-276. DOI: 10.1016/j.isprsjprs.2020.08.013.

Zakrzewski, W.T. and M. Penner. 2013. A comparison of tree stem taper models for use in Ontario. Ontario Forest Research Institute, Queen's Printer for Ontario. Forest Research Report No. 176. 26 p. 